\title{
SEDIMENTARY FACIES AND ENVIRONMENTS OF THE SEDIMENTARY FILL OF SOUTHERN BIDA BASIN, NIGERIA.
}

OZULU, GEORGE UCHEBIKE, OKORO, ANTHONY UWAOMA AND ONUIGBO, EVANGELINE NJIDEKA

(Received 23 March 2021; Revision Accepted 15 May 2021)

\section{ABSTRACT}

Six lithofacies were identified in the Lokoja Formation, Southern Bida Basin: fanglomerate/ conglomerate lithofacies $(\mathrm{Gmc})$, fine to coarse-grained ferruginized weakly cross-bedded, pebbly sandstone lithofacies (Scx), fine to coarsegrained sandstone lithofacies (Sfc), silty claystone lithofacies (Csm), siltstone lithofacies (SIt) and lateritic ironstone lithofacies (Ilt). These were grouped into three lithofacies associations viz: alluvial fan, braided river channel, floodplain lithofacies association. Nine lithofacies were identified in the Ahoko Formation. These are: black-dark grey carbonaceous shale lithofacies (Shc), bioturbated ripple-laminated siltstone lithofacies (Sbr), poorly cross-laminated claystone lithofacies (CxI), concretionary/nodular ironstone lithofacies (Icn), medium to coarse-grained sandstone lithofacies $(\mathrm{Smc})$ fine grained, well-sorted, friable bioturbated herringbone cross-bedded sandstone lithofacies (Sxf), massive brownish claystone lithofacies $(\mathrm{Clm})$, massive claystone with lateritic ironstone lithofacies (Cli) and lateritic ironstones lithofacies (IIt). These have been grouped into three lithofacies associations viz: shallow marine lithofacies association, tidal-intertidal flat lithofacies association and floodplain lithofacies association. Similarly, three lithofacies were identified in the Agbaja Formation and have been grouped into two lithofacies association. These are: fine to medium-grained sandstone ironstone interbedded lithofacies (Sti), oolitic-pisolitic ironstone lithofacies (lop) and concretionary ironstone lithofacies (Icr). The lithofacies associations are: tidal-intertidal flat lithofacies association and shallow marine lithofacies association. Result of lithofacies analysis helped in interpreting the depositional environments. The Lokoja Formation is a product of a fluvial dominated alluvial system from debris/gravity flow in alluvial fan. This developed further into braided river channels and later meandering river during the closing stages. Sediments of the Ahoko Formation were deposited in tidal/intertidal flats and shallow marine environments while sediments of the Agbaja Formation were produced by a shallow marine system with a high tidal influence.

KEYWORDS: Lithofacies, Association, Depositional Environment, Model, Outcrops, Bida Basin

\section{INTRODUCTION}

The Bida Basin is an inland sedimentary basin situated in the central part of Nigeria and aligned parallel with the NW - SE trend of the Niger River. It stretches from Shegwa in Niger State north-west of the Niger-Benue Confluence, to Dekina in Kogi State south-east of the Confluence; central Nigeria.

Sedimentary environments generate characteristic lithofacies defined by variables such as texture, sedimentary structures, sand body geometry and local fossil contents (Okoro and Ezeh, 2010). Walker (1984) cited in Okoro et al., (2012); defined facies as a body of rock showing lateral variations in the aspects of defined lithological characteristics. Adeleye, (1973, 1974), (Braide, 1992a), Akande, et al., (2005, 2006), Obaje, et al., (2011), Omali, et al., (2011), Osokpor and Okiti, (2013), Osokpor, et al., (2013), and Nton and Adamolekan (2016), have all described the sedimentary rocks of the southern Bida Basin from various perspectives. Adeleye, $(1973,1974)$ divided the sedimentary rocks into three stratigraphic units: the Lokoja Formation, Patti Formation and Agbaja Ironstone Formation.

In order to accurately define environments of sedimentary fills, sedimentary facies must be well defined, properly described and illustrated using

Ozulu, George Uchebike, Department of Earth Sciences, Salem University Nigeria, P.M.B. 1060 Lokoja.

Okoro, Anthony Uwaoma, Department of Geological Sciences, Nnamdi Azikiwe University P.M.B. 5025 Awka, Nigeria. Onuigbo, Evangeline Njideka, Department of Geological Sciences, Nnamdi Azikiwe University

P.M.B. 5025 Awka, Nigeria. 
lithofacies analysis. Lithofacies analysis entails the description of well sections and outcrop sections using the lithological characteristics such as textures, sedimentary structures, sand body geometry (grain size), contact types, bed thicknesses, fossil contents, etc.; to identify and interpret their depositional environments (Walker, 1984).

Over time, lithofacies in the Southern Bida Basin have not been well defined, properly described or illustrated with photographs to represent their corresponding outcrops. Lithologic rock-types belonging to the Lokoja Formation were identified as conglomerates, coarse grained pebbly sandstones, claystones, siltstones, ironstones and lateritic ironstone capping (Adeleye, 1973, 1974; Braide, 1992a; Omali et al., 2011). All these were, however, without clear-cut defined lithofacies or outcrop photographs to represent the lithofacies. Osokpor and Okiti (2013) identified one main lithofacies (sand) and three sub-lithofacies - fine-grained sand, medium-grained sand and coarse-grained sand; for the outcropping sediments in the Southern Bida Basin. Osokpor, et al., (2013), identified three main lithofacies sand, shale and silt. They also defined seven subfacies - silty sand, fine-grained sand, medium-grained sand, coarse-grained sand, clayey siltstone, silty clay, and sandy silt. They, however, did not reconcile the lithofacies with their corresponding outcrop exposures.
Nton and Adamolekan (2016) presented interpreted log sections of outcrops studied but did not clearly define the lithofacies.

The present study is a detailed systematic outcrop description of the various lithofacies and lithofacies associations distinguished using observable field characteristics. Lithofacies were critically evaluated and grouped into lithofacies association to correctly interpret their depositional environments. Field sedimentological evaluations were made in four localities: Lokoja, Agbaja, Ahoko, and Abaji to identify, define and describe the lithofacies type. The interpreted depositional environments and depositional systems were reconstructed on the basis of the sediments characteristics - lithology, texture, grain size, sedimentary structures, contact types, bed thicknesses as well as fossil contents.

The study area, which is the Southern part of the basin; lies within lat. $7^{0} 51^{\prime} \mathrm{N}$ - lat. $8^{0} 30^{\prime} \mathrm{N}$ and long. $6^{0} 30^{\prime} \mathrm{E}$ long. $7^{0} 00^{\prime} \mathrm{E}$ (Fig. 1). The rocks studied are exposed as outcrops on road-cuts or quarry pits and are accessible using major roads like the Lokoja - Abuja highway, the Gegu-Gerinya road and the earth road from Lokoja Agbaja village. The name Patti Formation, as used in stratigraphic nomenclature, has been reviewed by Rahaman et al., (2019) and a new name Ahoko Formation proposed instead of Patti Formation.

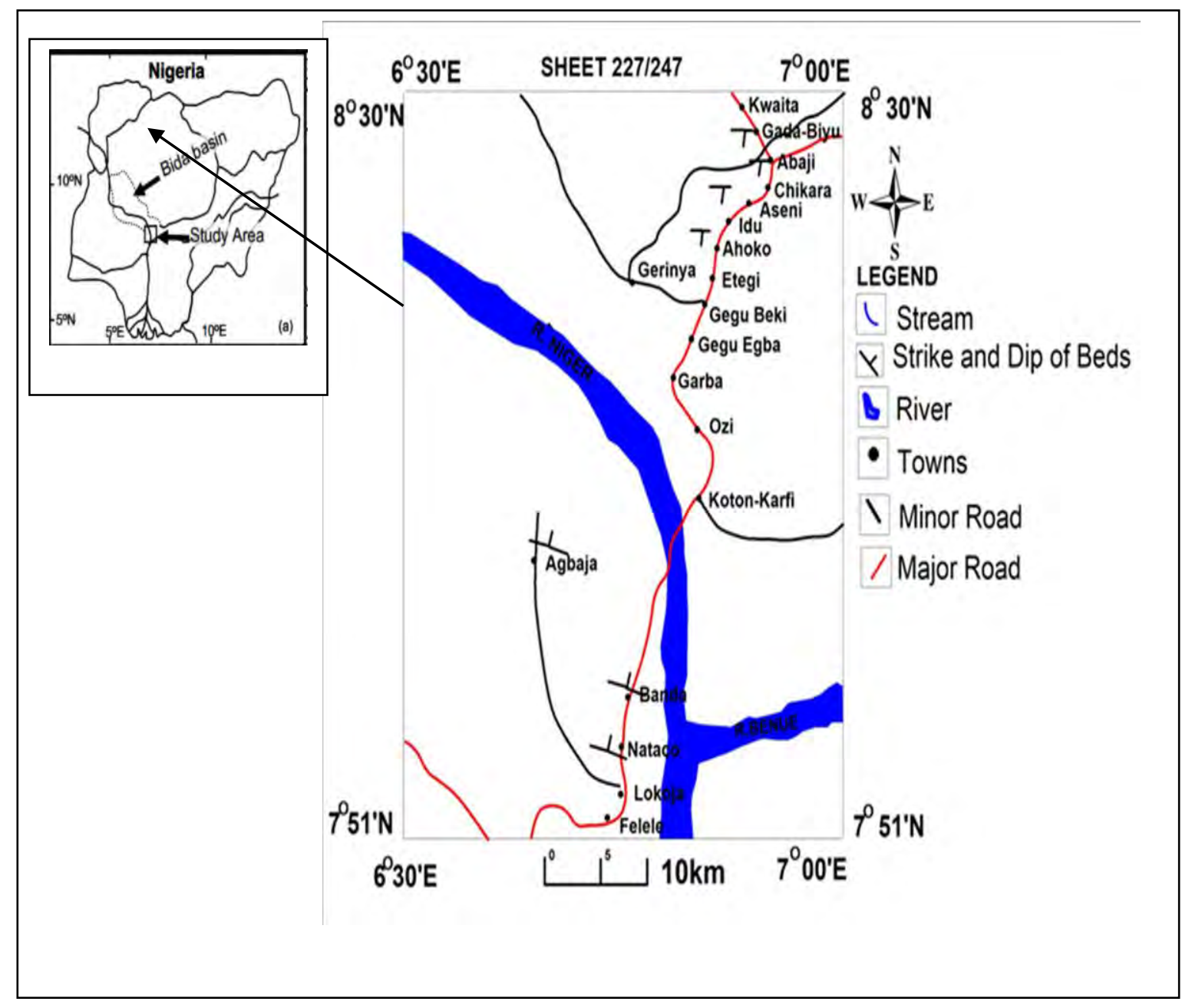

Fig. 1: Location Map of the Southern Bida Basin showing the Study Area 


\section{GEOLOGY OF STUDY AREA}

The geological setting of the Bida Basin shows that it is situated between the Precambrian Northern Nigeria massif and the West African craton. This is delimited in the north-east by the Basement Complex and southwest by the West African craton (Braide, 1992b) (Fig. 2). In terms of its sedimentary fill, the basin merges with the Sokoto Basin in the north-west and the Anambra basin in the south-east (Adeleye, 1974, Ojo, and Akande, 2009, Obaje et al., 2011, Nwajide, 2013). Although the boundary of the basin with the Anambra Basin does not appear clear-cut nor is it readily traceable on outcrops, the rocks are either interdigitating across the basin boundary or display facies changes (Nwajide, 2013).

The Bida Basin is said to be a gently down-warped trough whose origin is closely related to the Benue Trough and part of the West and Central African Rift
System (Benkhelil, 1989; Obaje et al., 2011). It covers an area of about $7,000 \mathrm{~km}^{2}$ from the confluence of the Niger-Benue Rivers in the northern part of Nigeria with its maximum width, in the middle Niger area, reaching $160 \mathrm{~km}$ (Ojo, and Ajakaiye, 1989). Three physiographical units have been recognized: (i) The Niger River physiographic unit with its floodplains and distributaries, (ii) The belt of mesas and buttes and (iii) The plains (Adeleye, 1989).

The basin has been divided geographically into two regions by Obaje, et al., (2013); the Northern Bida Basin and the Southern Bida Basin. Although no concrete line of demarcation between them has been identified, an approximate boundary has, however, been fixed. The southern part extends from the confluence of the Niger Benue River at Lokoja in Kogi State up to Abaji in the Federal Capital Territory (Nton and Adamolekun, 2016).

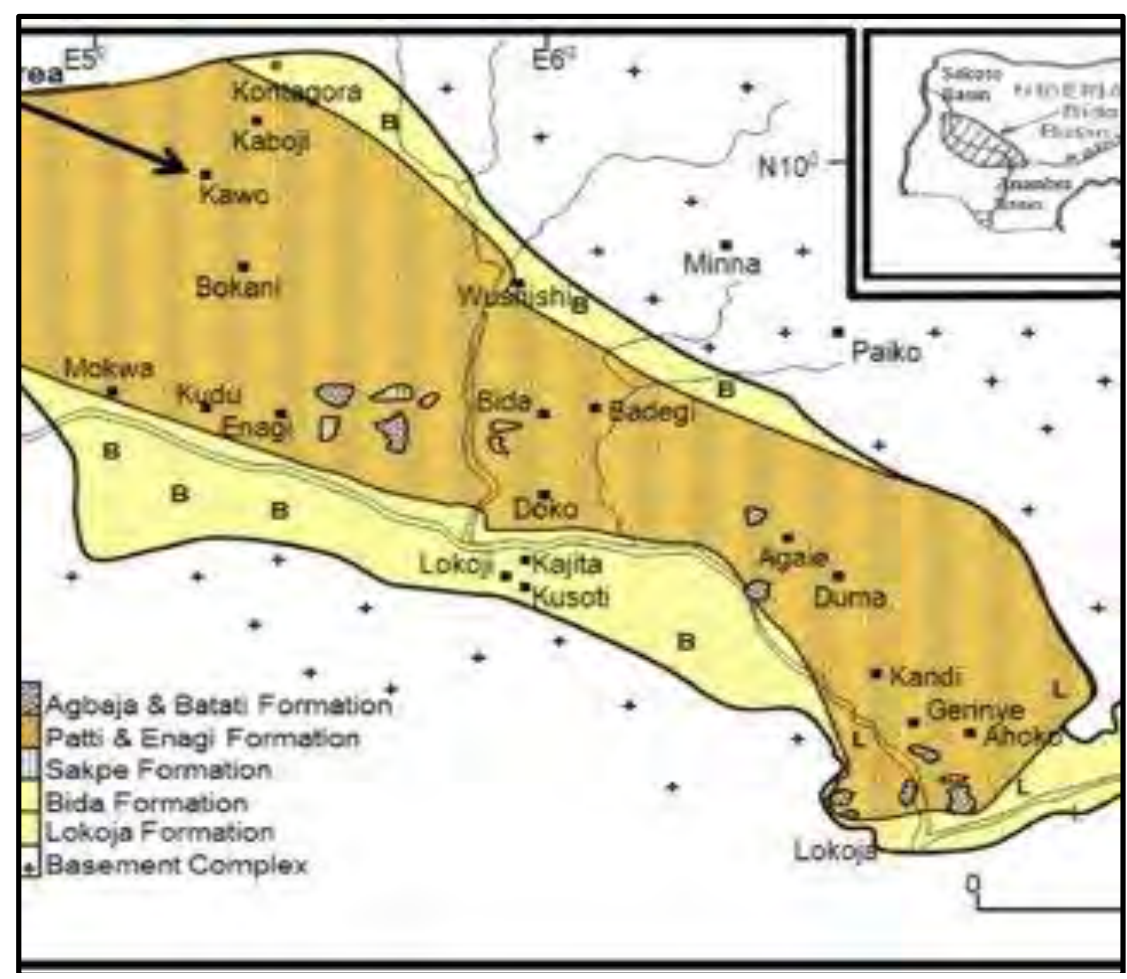

Fig. 2: Regional geological map of the Bida Basin (after Braide, 1992c).

\section{METHOD OF STUDY}

The methods adopted in this study consist of field geological mapping and lithostratigraphic description of exposed outcrop sections. This is with respect to the lithologic types (lithotypes), textures, sedimentary structures (physical, chemical and biogenic), bed thicknesses and contact types as well as fossil contents. The lithostratigraphy presented is based on lithologic description of outcrops observed from road cut exposures, quarry pits and stream channels while outcrop photographs of some described sections were taken to show the characteristic features of the lithofacies. Individual lithofacies were grouped into lithofacies associations based on the concept of lithofacies relationship (Rodriguez, 1989; Reijers, 1995); and then used to interpret the paleoenvironment of deposition. Depositional models for the formations were developed using the lithofacies associations while the geologic map showing the different formations in the study area was produced using the merged topographic sheets of Lokoja NW and Koton-Karfe NW.

\section{RESULTS AND DISCUSSION \\ LITHOFACIES OF THE LOKOJA FORMATION}

Six lithofacies were identified in the Lokoja Formation. These are: the fanglomerate/conglomerate $(\mathrm{Gmc})$, the fine to coarse-grained ferruginized weakly crossbedded, pebbly sandstone (Scx), the fine to coarsegrained sandstone (Sfc), the massive silty claystone (Csm), the siltstone (SIt) and the lateritic ironstone (IIt) lithofacies. These have been grouped into three lithofacies associations viz: the alluvial fan, braided river channel and floodplain lithofacies associations.

\section{ALLUVIAL FAN LITHOFACIES ASSOCIATION Fanglomerate/conglomerate lithofacies (Gmc)}

This lithofacies association comprise both the clastsupported and the matrix-supported fanglomerate/conglomerate lithofacies $(\mathrm{Gmc})$. The clastsupported conglomerate sub-lithofacies is essentially made up of pebble and cobble clasts in sandstone matrix and could be described as conglomerates or 
fanglomerates due to their gravelly size clast. The clast consists mainly of angular to sub-round quartz and feldspar grains and are described as clast-supported as individual clasts or grains touch and supports each other in place. This lithofacies usually occurs as the basal unit lying unconformably on the uneven Basement Complex where exposed. In the matrix-supported conglomerate sub-lithofacies, the individual quartz or feldspar grains do not support each other but rather float in sandstone matrix with clay/mud admixtures that have formed cracks in some places around Felele. This lithofacies is equally exposed as the basal conglomerate lying unconformably on the Basement Complex in most places. The grains of this conglomerate floats in muddy white or reddish-brown matrix and is clearly seen as you move from Felele to Banda up to Koton-Karfe. The angular to sub-round pebble and cobble clasts are often found lying parallel to the bedding plane. At the Agbaja section, the matrix-supported conglomerate occurs in place.

At the Abaji road-cut section, the massive paraconglomerate floats in purplish-white sandstone matrix. The angular to sub-round quartz pebbles and cobbles do not support each other but rather are found floating in sandstone matrix. This lithofacies is exposed at the base of the section. Both the clast-supported and matrix-supported conglomerate sub-lithofacies are indicative of debris-gravity induced alluvial processes. The clast-supported fanglomerate/conglomerate sublithofacies is shown in fig. 3 as exposed in Felele.
Angular to sub-round quartz and feldspar cobbles and pebbles are quite ubiquitous as individual clasts or grains are seen to support each other. The matrixsupported fanglomerate/conglomerate sub-lithofacies is shown in fig. 4 exposed at a stream channel in Agbaja road section with the individual quartz or feldspar grains floating in sandstone matrix with mud admixtures.

The clasts-matrix supported fanglomerate/conglomerate lithofacies is equally interpreted as alluvial fan deposits from debris flow system. Alluvial fan sediments have been reported to be dominated by gravelly deposits which typically show down-fan decrease in grain sizes and bed thicknesses as well as an increase in sediments setting (Boggs, 2006). These sediments are interpreted as debris-flow-dominated alluvial fan deposits characterized by lobes of poorly sorted coarse sediments commonly embedded in mud matrix while sediments on alluvial fans are also typically poorly sorted and include abundant gravel-size detritus (Boggs, 2006). The interpretation of the fanglomerate/conglomerate lithofacies of the Lokoja Formation as alluvial fan deposits from debris flow is justified by the observed characteristics in the outcropping sediments. Typical outcrop setting of this lithofacies occur as cycles of matrix-supported fanglomerate/conglomerate alongside fine to coarsegrained ferruginized weakly planar cross-bedded pebbly sandstone lithofacies capped by claystones (Figs. 5 \& 7). Interpretative deductions of their paleoenvironment have also been shown in figs. $6 \& 8$.

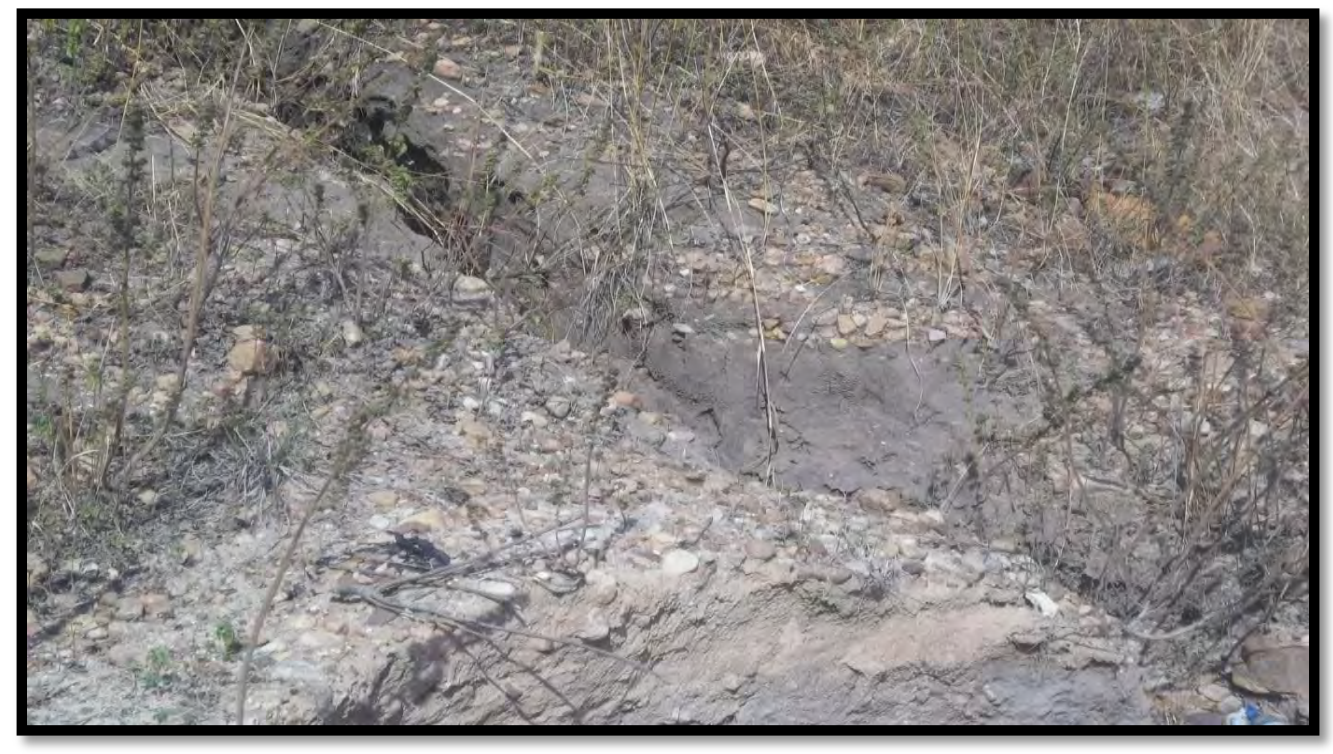

Fig. 3: Clast-supported fanglomerate/conglomerate exposed in Felele ( $07^{\circ} 51.307^{\prime} \mathrm{E} 006^{\circ} 41.891^{\prime}$ Elevation $-157.2 \mathrm{~m}$ ) 


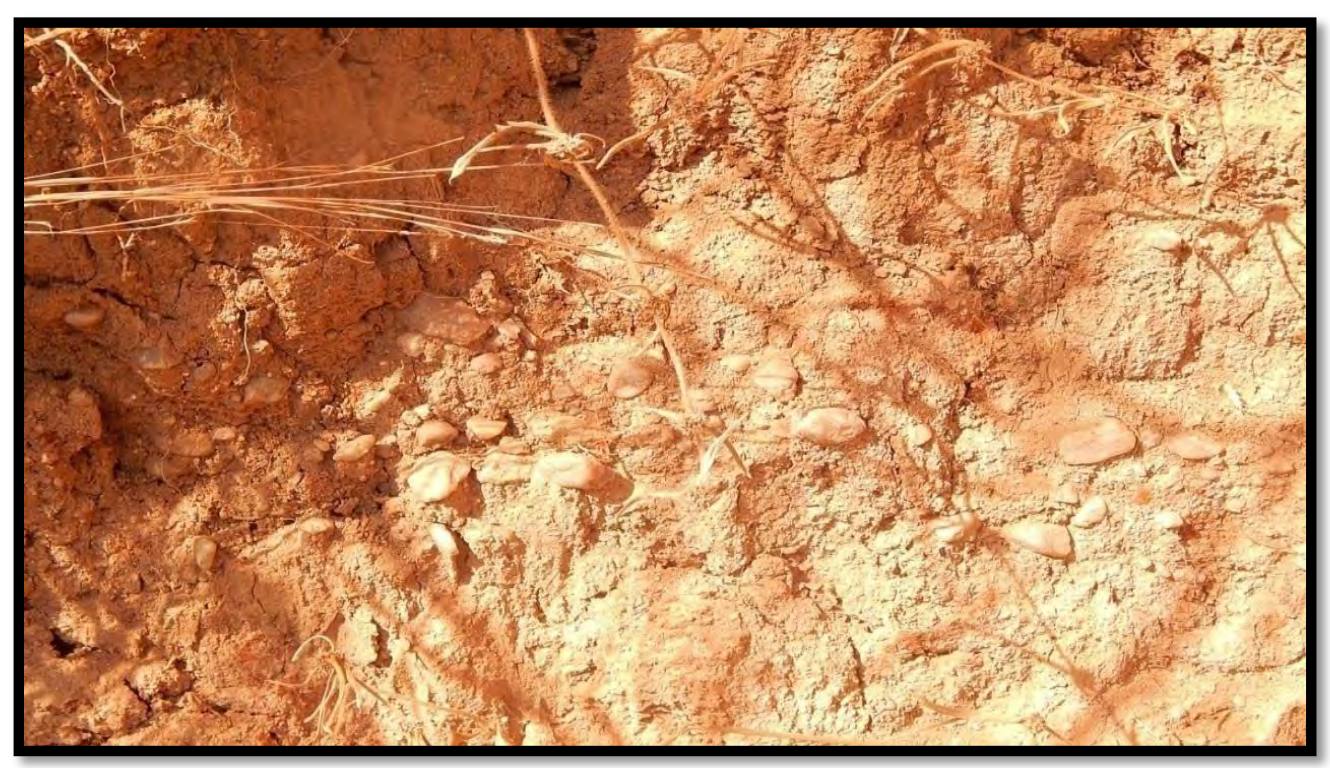

Fig. 4: Matrix-supported fanglomerate/conglomerate exposed at a stream channel in

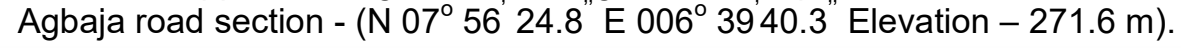

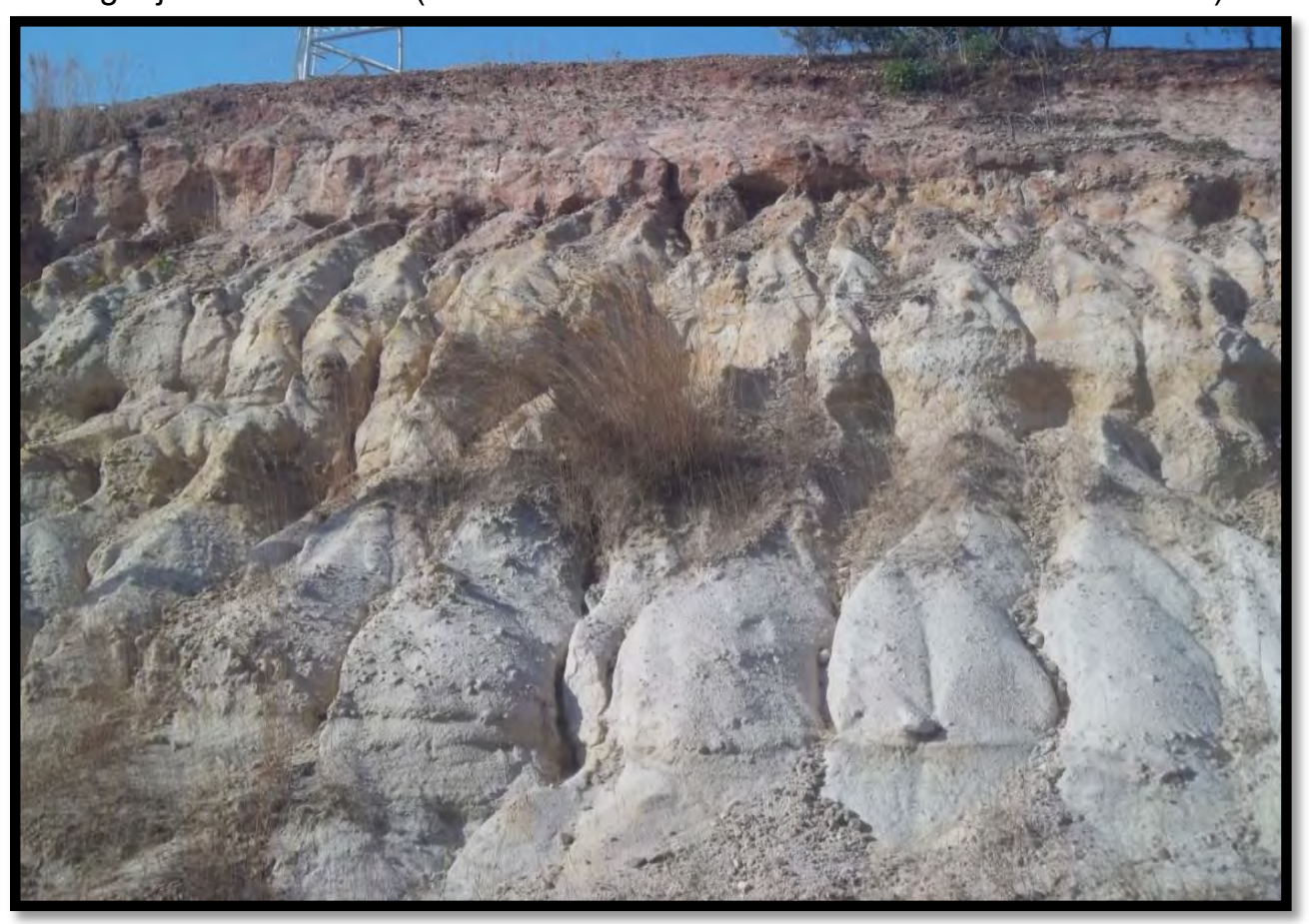

Fig. 5: Cycles of matrix-supported fanglomerate/conglomerate, fine to coarse-grained ferruginized weakly planar cross-bedded pebbly sandstone capped by claystones of Lokoja Formation exposed in Felele - $\left(\mathrm{N} 07^{\circ} 51.178^{\prime} \mathrm{E} 006^{\circ} 41.035^{\prime}\right.$ Elevation - $106.6 \mathrm{~m}$. Dip of Beds: NNE $\left.08^{\circ}\right)$. 


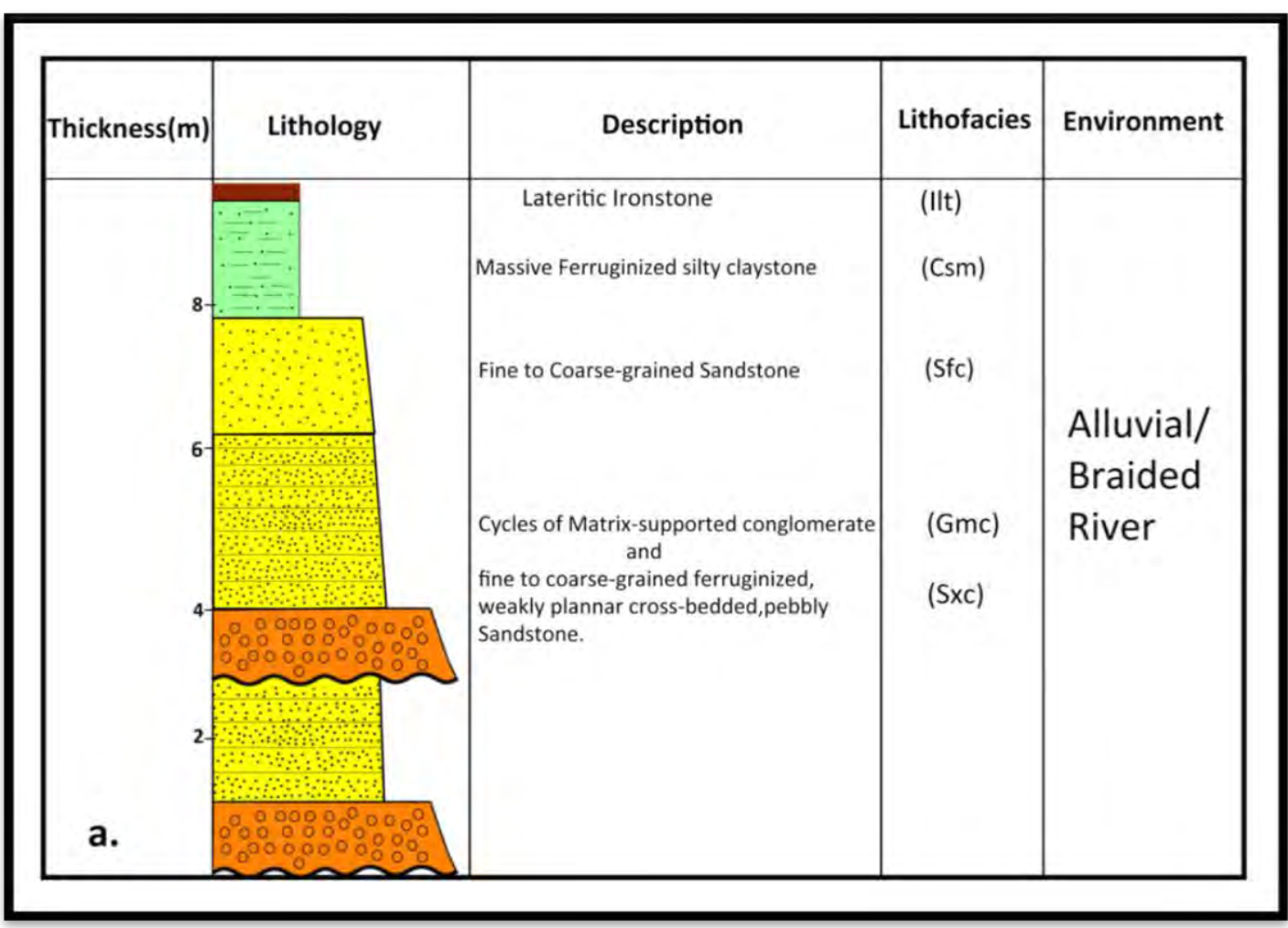

Fig. 6: Lithologic log showing cycles of matrix-supported fanglomerate/conglomerate, fine to coarse-grained ferruginized weakly planar cross-bedded pebbly sandstone capped by claystones of Lokoja Formation exposed in Felele

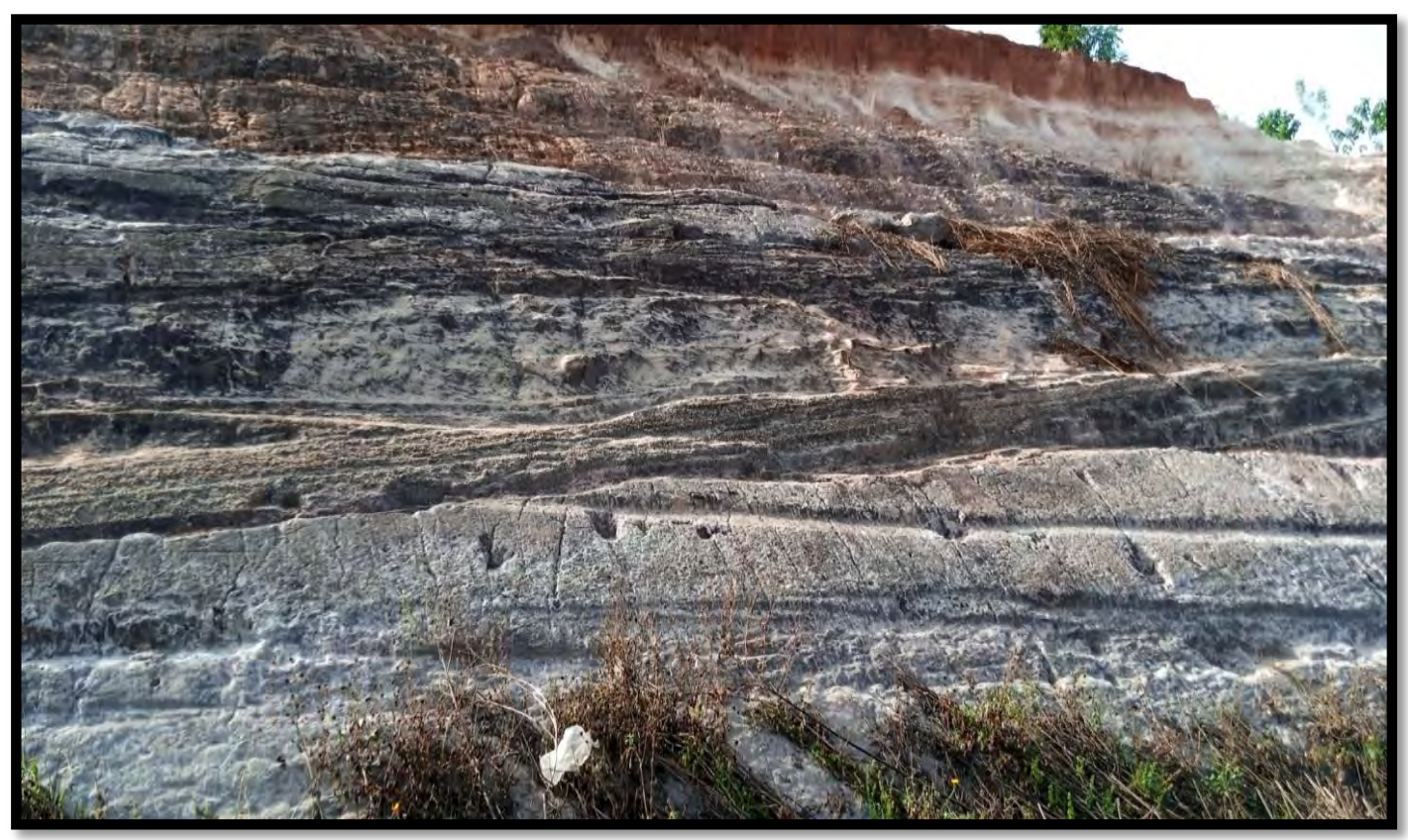

Fig. 7: Outcrop section showing cycles of massive purplish-white monomictic paraconglomerates, planar crossbedded sandstones capped by siltstones, claystones and lateritic ironstones exposed at Abaji - $\left(\mathrm{N} 08^{\circ} 2058.1^{\circ}\right.$ E $006^{\circ} 5308.5^{\prime \prime}$ Elevation - 142.6 m. Dip of Beds: SSW 06 ${ }^{\circ}$. 


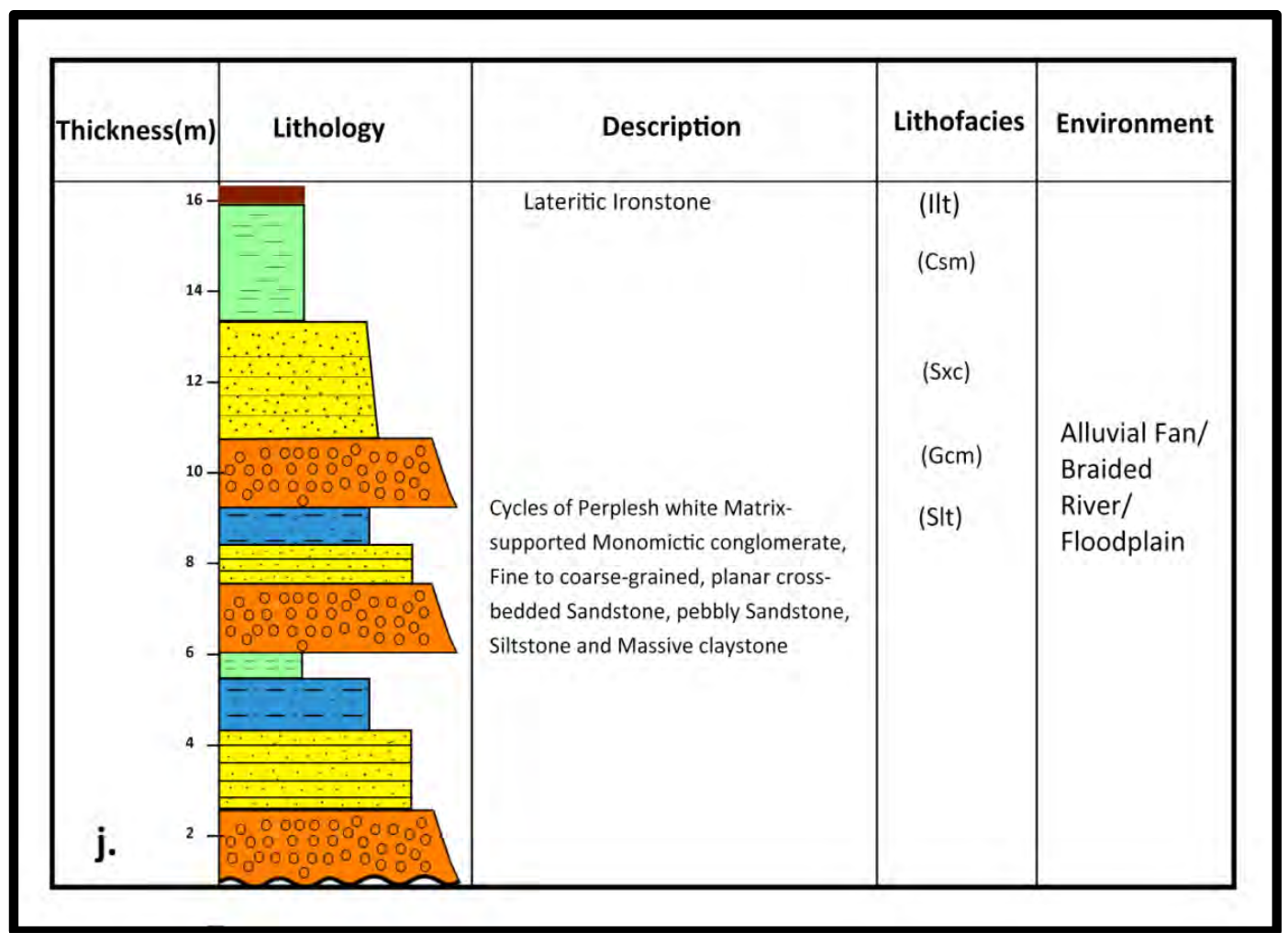

Fig. 8: Lithologic log showing cycles of massive purplish-white monomictic paraconglomerates, planar cross-bedded sandstones capped by siltstones, claystones and lateritic ironstones exposed at Abaji

\section{BRAIDED RIVER CHANNEL LITHOFACIES ASSOCIATION}

This lithofacies association is composed of the following lithofacies: fine to coarse-grained ferruginized, weakly cross-bedded pebbly sandstones (Sxc), fine to coarsegrained sandstone (Sfc), ferruginized silty claystone (Csm) exposed in Felele, Nataco and Banda while oolitic/lateritic ironstone bands (IIt) are seen as the capping that preserve the entire outcrops in the basin. All these have been interpreted as braided river deposits from a braided river channel system. These poorly sorted sandstones are either fine to coarse-grained or medium to coarse-grained with a fining upward sequence. They are made up of quartz and feldspar with sub-rounded to rounded grains of the same composition but varying sizes and are well exposed in Felele, Nataco, Banda, Agbaja road section and at Abaji road section. The characteristic weak cross-beddings and imbricate pebbles found in some of the outcrops, helped in defining this lithofacies as typical fluvial channel deposits or point bar deposits (Fig. 9). Braided deposits are usually characterized by cross-beddings and fining upward sequences (Boggs, 2006). The sandstones are sometimes embedded in clay ad-mixture in some places which are either white or reddish-brown in colour or found with clay drapes on the Agbaja road section (Fig. 10). The reddish-brown colouration is as a result of the intense paleo-redox processes in the ancient environment. Massive ferruginized silty claystone culminates the Lokoja Formation (Fig. 11). This cyclic sequence of the Lokoja Formation is clearly exposed in places like Felele, Nataco and Banda; all in Lokoja metropolis. Its interpreted lithologic log is also shown in fig. 


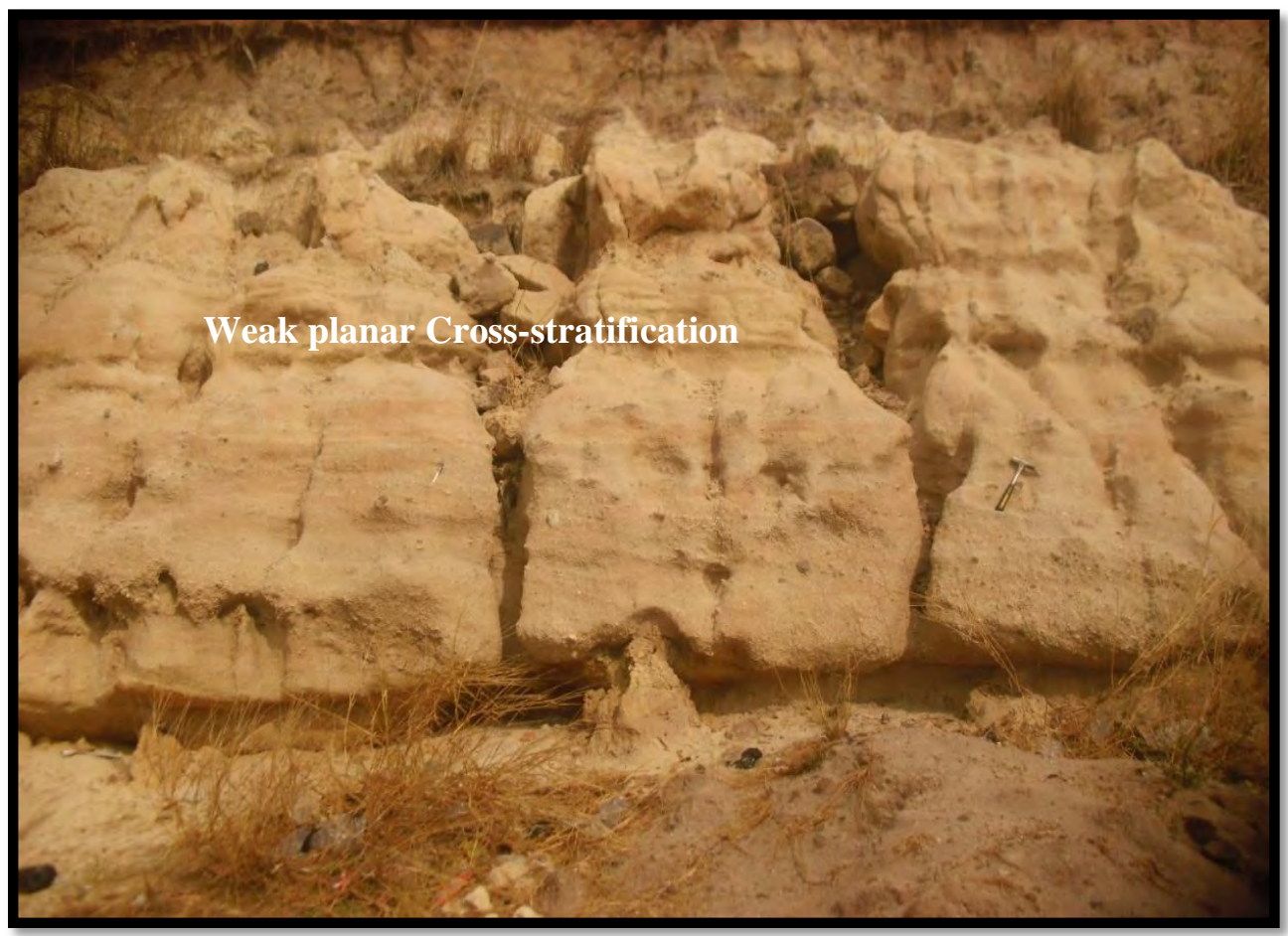

Fig. 9: Fine to coarse-grained ferruginized, weakly planar cross-bedded sandstone with wedge-shaped geometry exposed at Nataco - ( $07^{\circ} 51.178$ E $006^{\circ} 45.567$ Elevation - $\left.63 \mathrm{~m}\right)$.

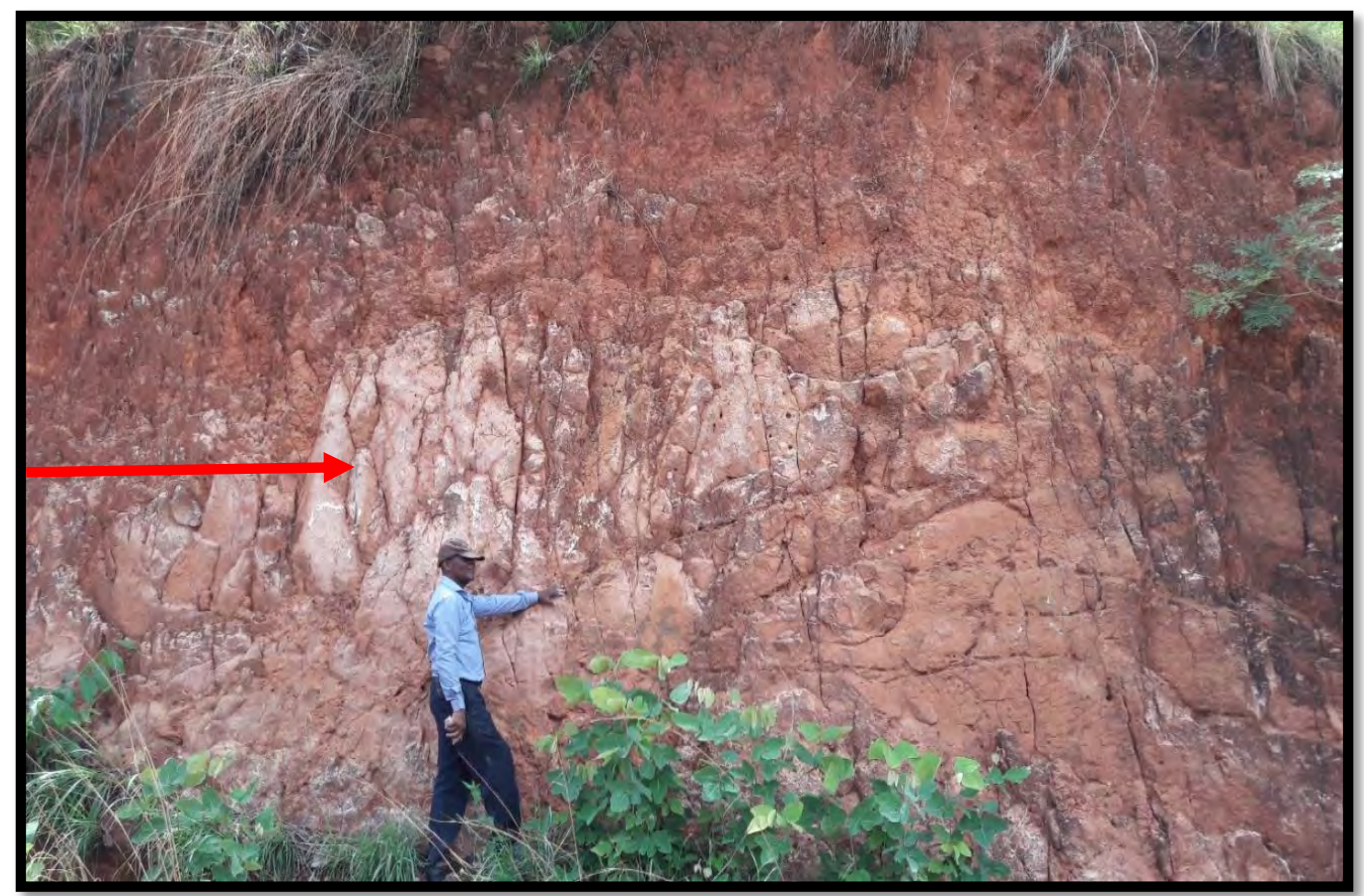

Fig. 10: Fine to coarse-grained sandstone with clay drapes exposed at the Agbaja road section - ( $07^{\circ} 56^{\prime} 24.8^{\prime \prime}$ E $006^{\circ} 3940.3^{\prime \prime}$ Elevation - $\left.271.6 \mathrm{~m}\right)$ 


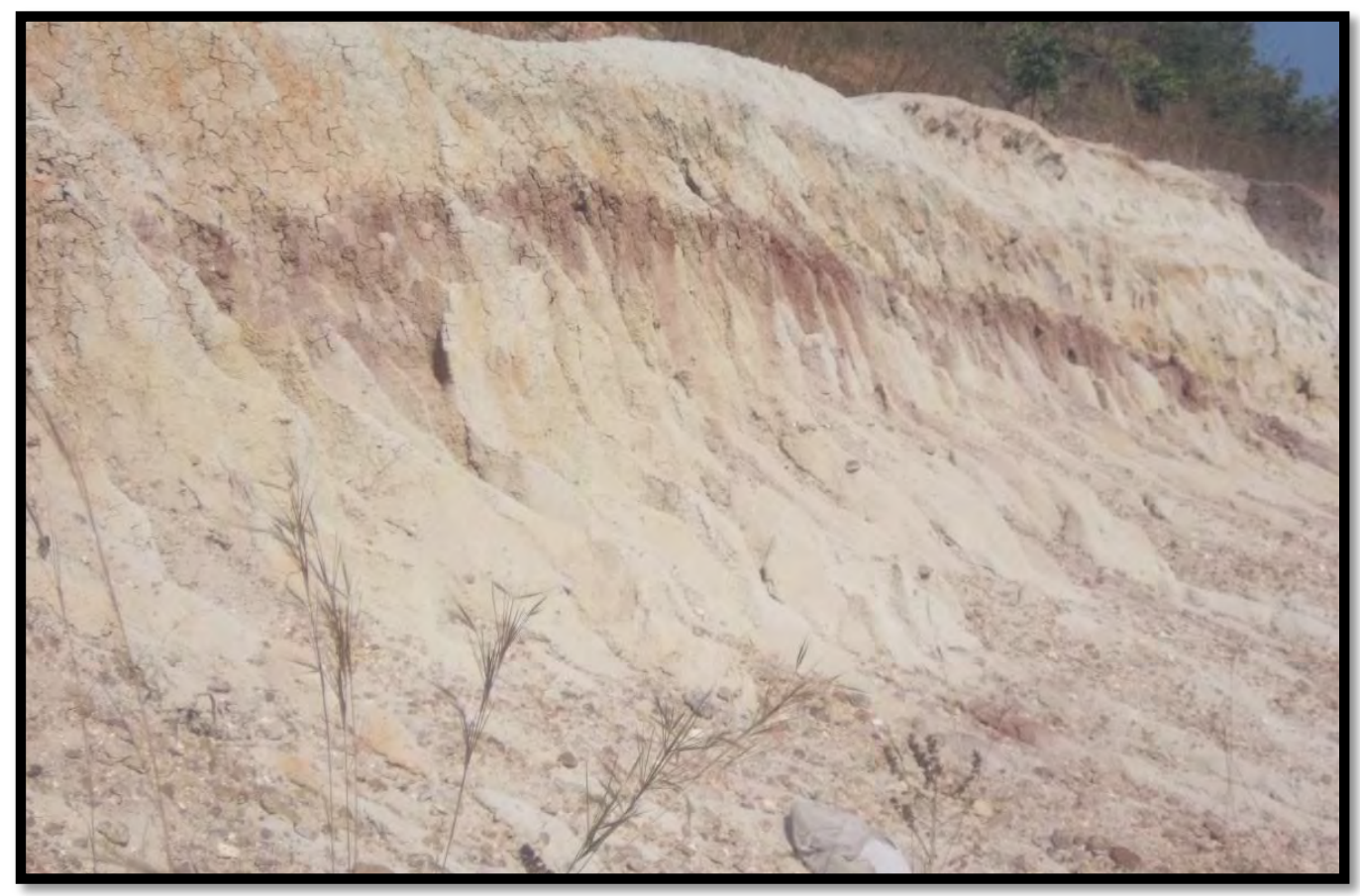

Fig. 11: Massive ferruginized silty claystone exposed in Felele - ( $\mathrm{N} 07^{\circ} 51.284^{\prime} \mathrm{E} 006^{\circ} 43.032^{\prime}$ Elevation - 114.9 m. Dip of Beds: NNE 06 ${ }^{\circ}$.

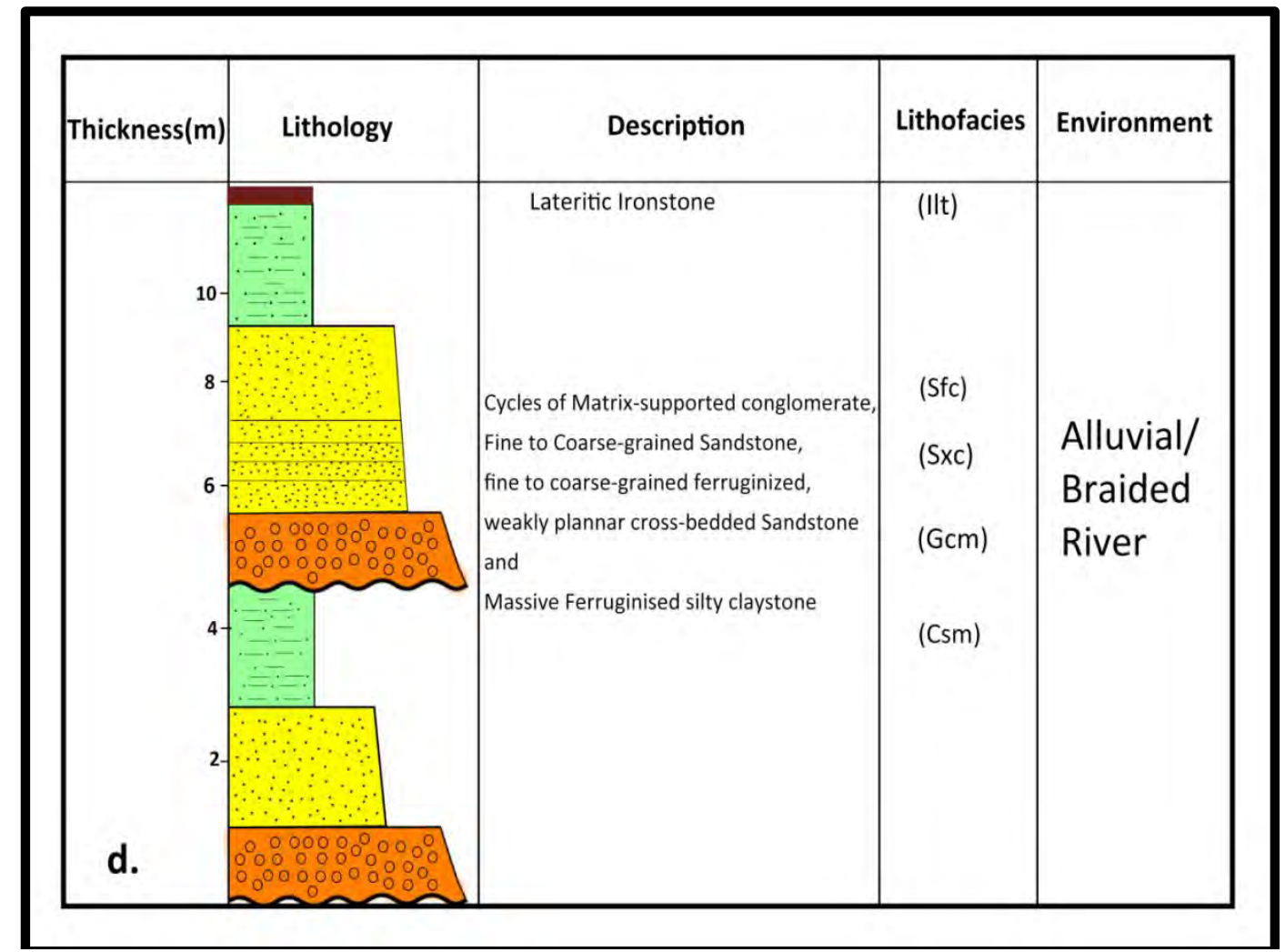

Fig. 12: Log showing cycles of matrix-supported fanglomerate/conglomerate, weakly planar pebbly sandstones, fine to coarse-grained sandstones capped by claystones exposed in Nataco

\section{FLOODPLAIN LITHOFACIES ASSOCIATION}

The Floodplain Lithofacies Association consist of massive claystone (Csm) and siltstone (SIt) deposits exposed in Gada-Biyu and Abaji section (Figs. 7 \& 13). These mud-size quartz grains are products of overbank floodplain depositional process inundated by a fluvial meandering river system (Boggs, 2006). In Gada-Biyu, the claystones occur as channel fills with festoon trough cross-stratification structures which are records of dispersed turbulence within the channels. The interpreted lithologic log is shown in fig. 14. At the Abaji road section, the claystones are found at the uppermost part of the section and show high abundance of kaolinitic 


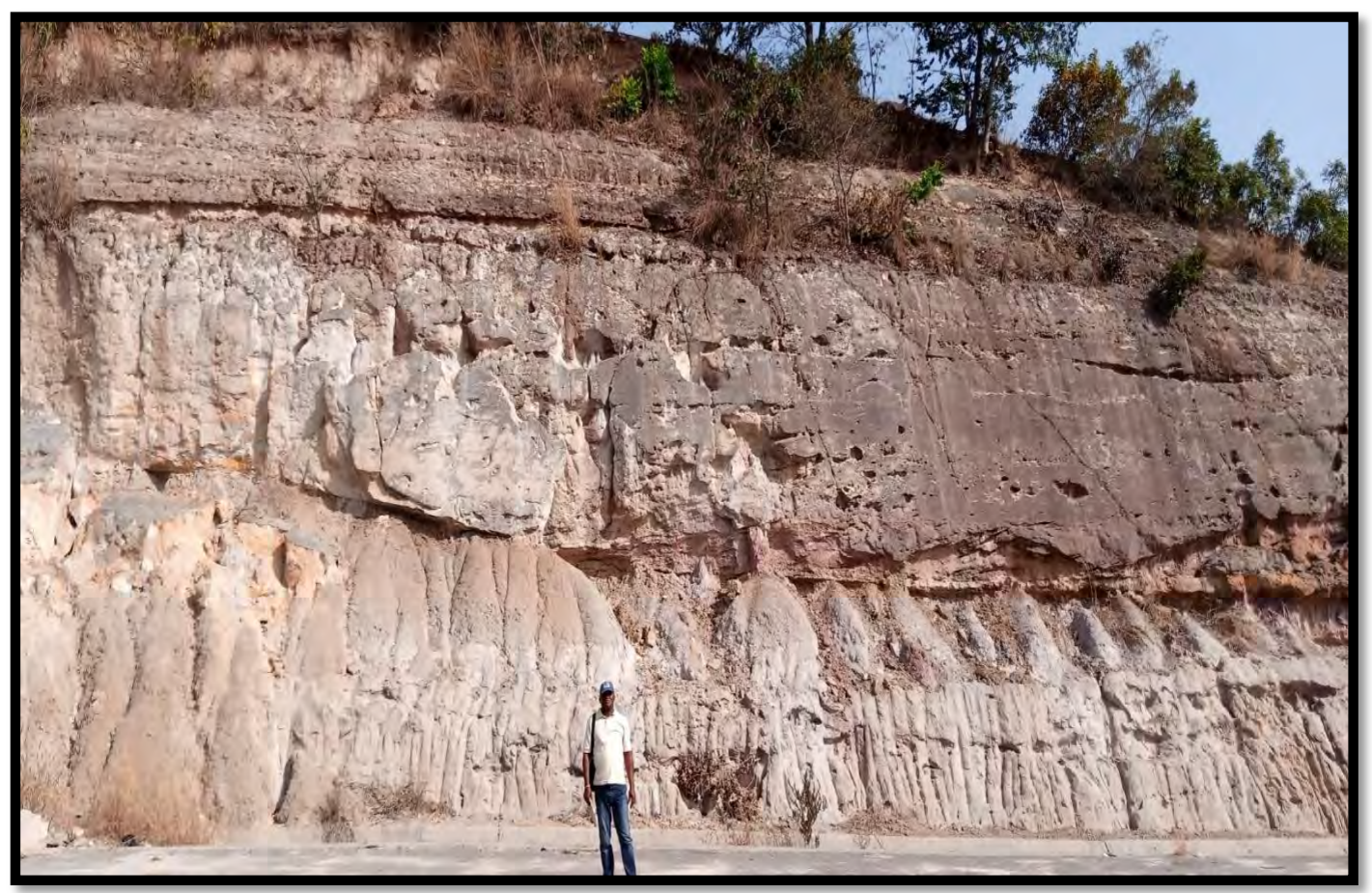

Fig. 13: Outcrop showing thick section of cycles of fining upwards sandstones - claystones sequence exposed at Gada-Biyu - (N $08^{\circ} 36^{\prime} 43.6^{\prime \prime}$ E $006^{\circ} 54^{\prime} 49.4^{\prime \prime}$ Elevation - 108 m. Dip of Beds: SSW $\left.04^{\circ}\right)$.

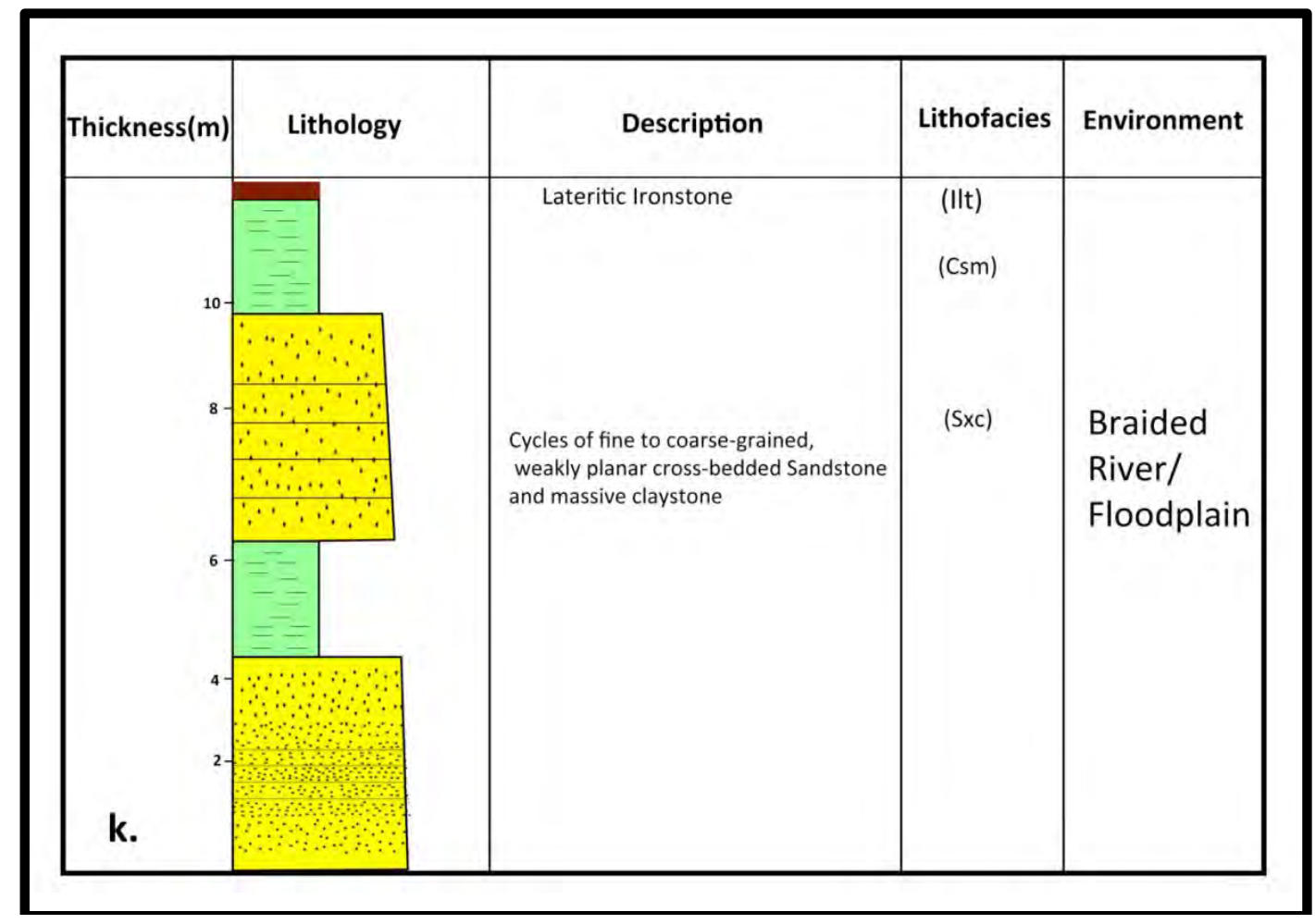

Fig. 14: Lithologic log showing thick section of cycles of fining upwards sandstones - claystones sequence exposed at Gada-Biyu

\section{LITHOFACIES OF THE AHOKO FORMATION}

Nine lithofacies were identified in the Ahoko Formation. These are: the black-dark grey carbonaceous shale (Shc), the bioturbated ripple-laminated siltstone (Sbr), the poorly cross-laminated claystone (CxI), the concretionary/nodular ironstone (Icn), the medium to coarse-grained sandstone $(\mathrm{Smc})$ the fine grained, wellsorted, friable bioturbated herringbone cross-bedded sandstone (Sxf), massive brownish claystone $(\mathrm{Clm})$, massive claystone with lateritic ironstone (Cli) and lateritic ironstones (IIt). These have been grouped into three lithofacies associations viz: the shallow marine lithofacies association, the tidal-intertidal flat lithofacies association and floodplain lithofacies association.

\section{SHALLOW MARINE LITHOFACIES ASSOCIATION}

This lithofacies association is composed of black to dark grey carbonaceous shale found at Ahoko, Gegu and Gerinya. The shale unit appears black in some places 
and dark grey at other places. This lithologic unit change laterally into mudstones (claystones) at some locations and is quite prominent at the base of the Ahoko section (Fig. 15). Braide, (1992b) and Agyingi, (1991), earlier suggested non marine environments for the argillaceous rocks (shale - clay) unit. However, Ojo, O. J. and Akande, $(2006,2008)$ reported the presence of marine dinoflagellates in some intervals of the formation while Ojo, O. J. (2009) also reported marine dinocysts assemblage of the genera Dinogymnium, Senegalinium, Andalusiella and Spiniferites in the sections. The poor fissility or blocky nature of the shale depicts low energy deposits of shallow/marginal marine environment. The interpreted lithologic log is shown in fig. 16.

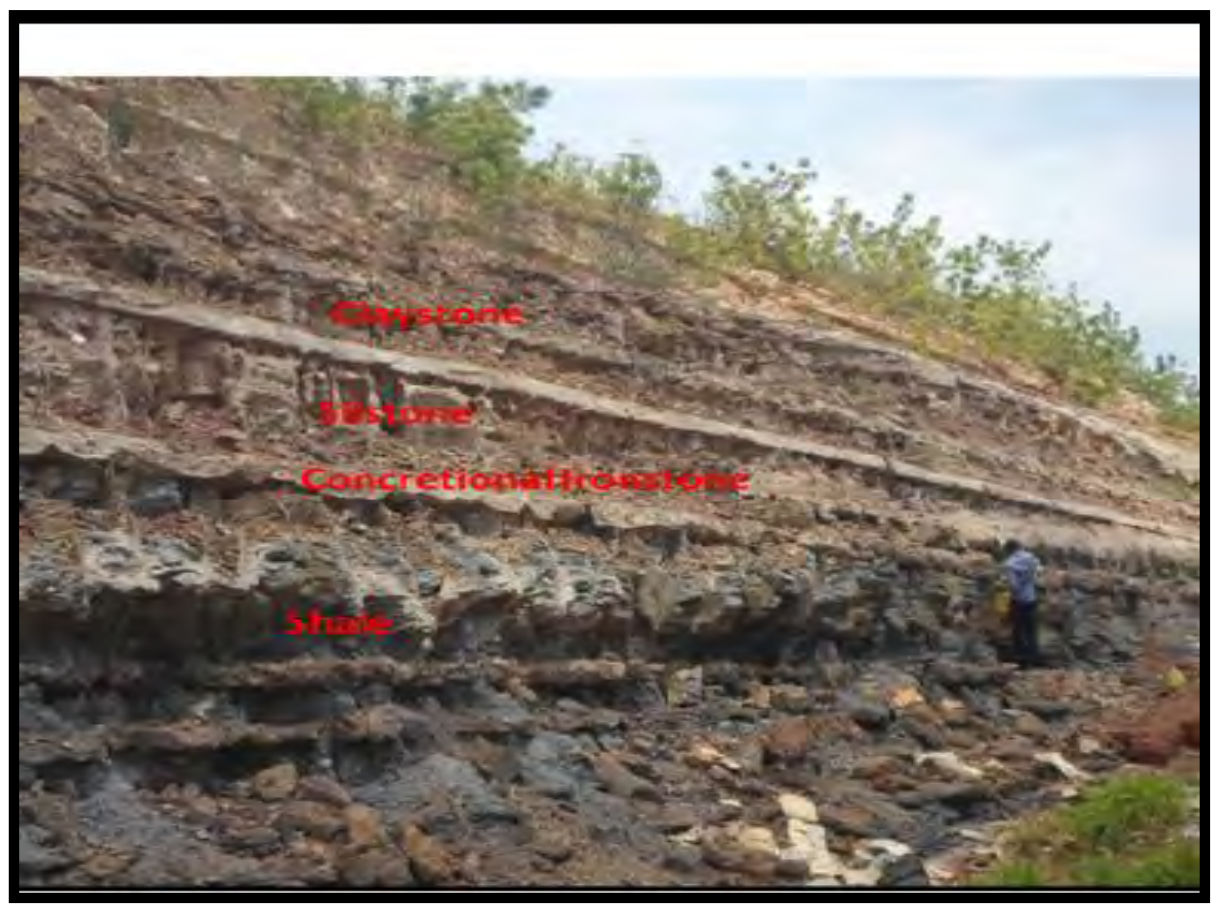

Fig. 15: Outcrop section showing poor fissile black to dark grey carbonaceous shales and siltstone - claystone heteroliths exposed in Ahoko ( $\mathrm{N} 08^{\circ} 18.161^{\prime} \mathrm{E} 006^{\circ} 51.822$ Elevation - 98.5 m. Dip of Beds: SSW 02 ${ }^{\circ}$ ).

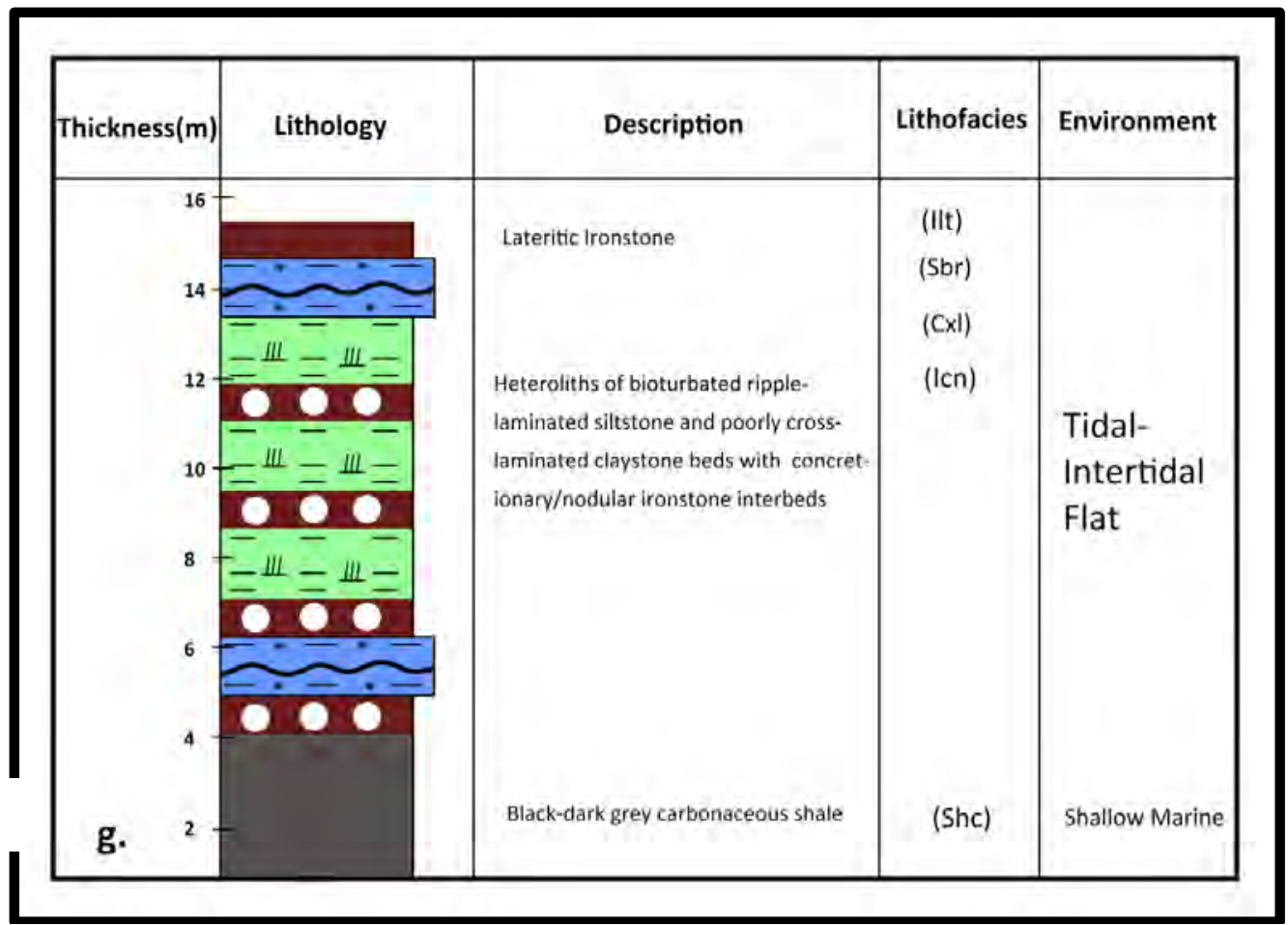

Fig.16: Lithologic log section showing shale and siltstone - claystone heteroliths exposed in Ahoko 


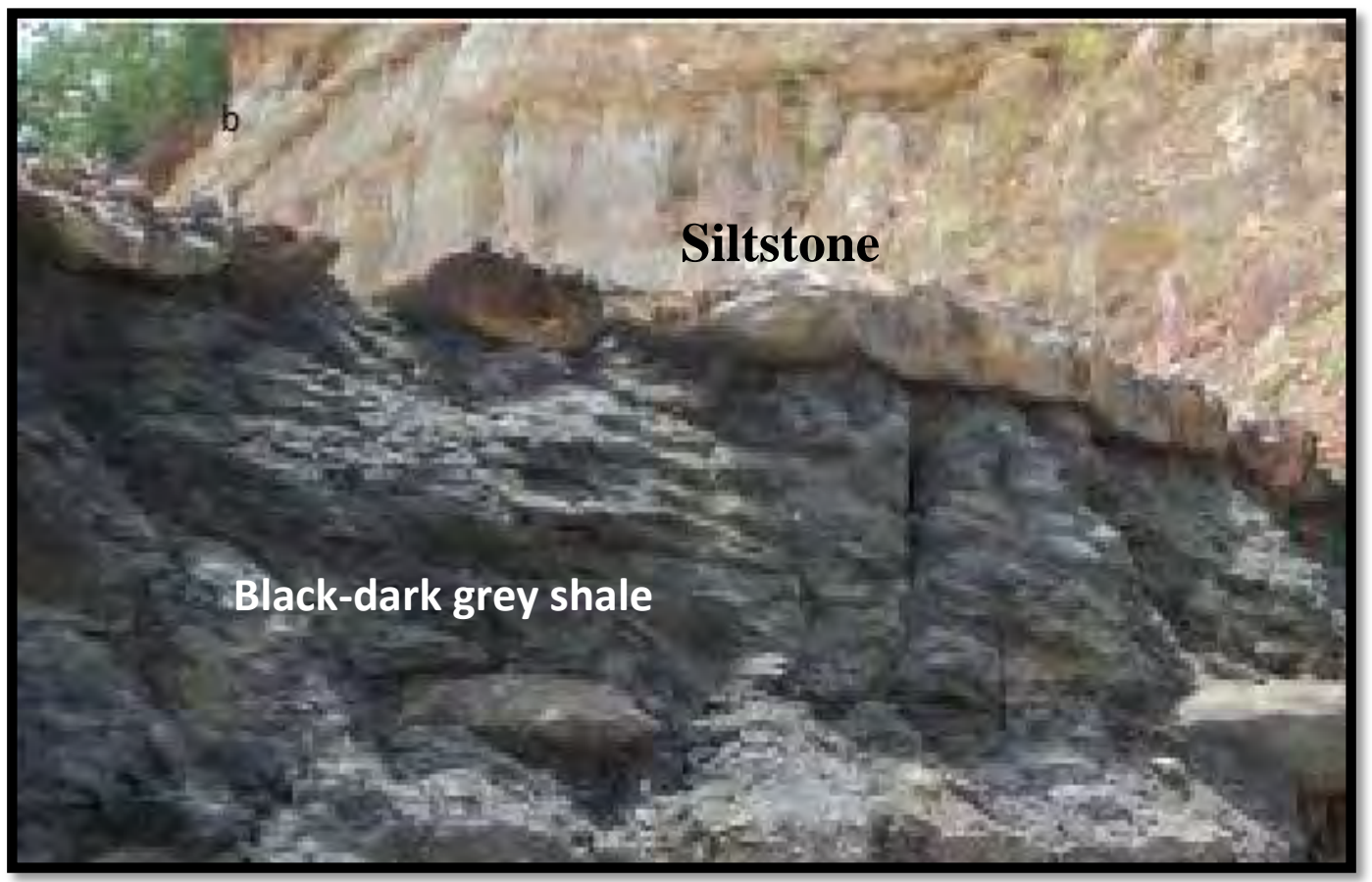

Fig. 17: Black-dark grey carbonaceous shale lithofacies overlain by bioturbated ripple-laminated siltstone lithofacies exposed in Ahoko village - ( $08^{\circ} 18.161^{\prime} \mathrm{E} 006^{\circ} 51.822^{\prime}$ Elevation - $98.5 \mathrm{~m}$. Dip of Beds: SSW $\left.02^{\circ}\right)$.

\section{TIDAL-INTERTIDAL FLAT LITHOFACIES ASSOCIATION}

This association consists of the following lithofacies: the bioturbated ripple-laminated siltstone (Sbr), the poorly cross-laminated claystone $(\mathrm{Cxl})$, the concretionary/nodular ironstone (Icn), the medium to coarse-grained sandstone (Smc), the fine grained, well-sorted, friable bioturbated herringbone crossbedded sandstone (Sxf) and the lateritic ironstone lithofacies (IIt).

The bioturbated ripple-laminated siltstone lithofacies (Sbr) is found at the Ahoko road-cut section and at the Agbaja road section (figs. $17 \& 18$ ). At the Ahoko roadcut section, the yellowish siltstone lithofacies (due to oxidation process), has ripple-laminations with slump structures, discrete burrows of Chondrites (branching galleries of endobenthic probing worms), Thallasinoides (horizontal branching burrows), Ophiomorpha (cryptic bioturbation burrows) and liesegang concentric ringed structures, which are products of secondary chemical weathering. At the Agbaja road section, the wavy-parallel laminated siltstone lithofacies overlies the fine grained, wellsorted, friable bioturbated herringbone cross-bedded sandstone leaving an erosional contact between the bedding planes (figs.18 \& 19). This unit is interpreted as a tidal-intertidal flat deposit (Fig. 20).

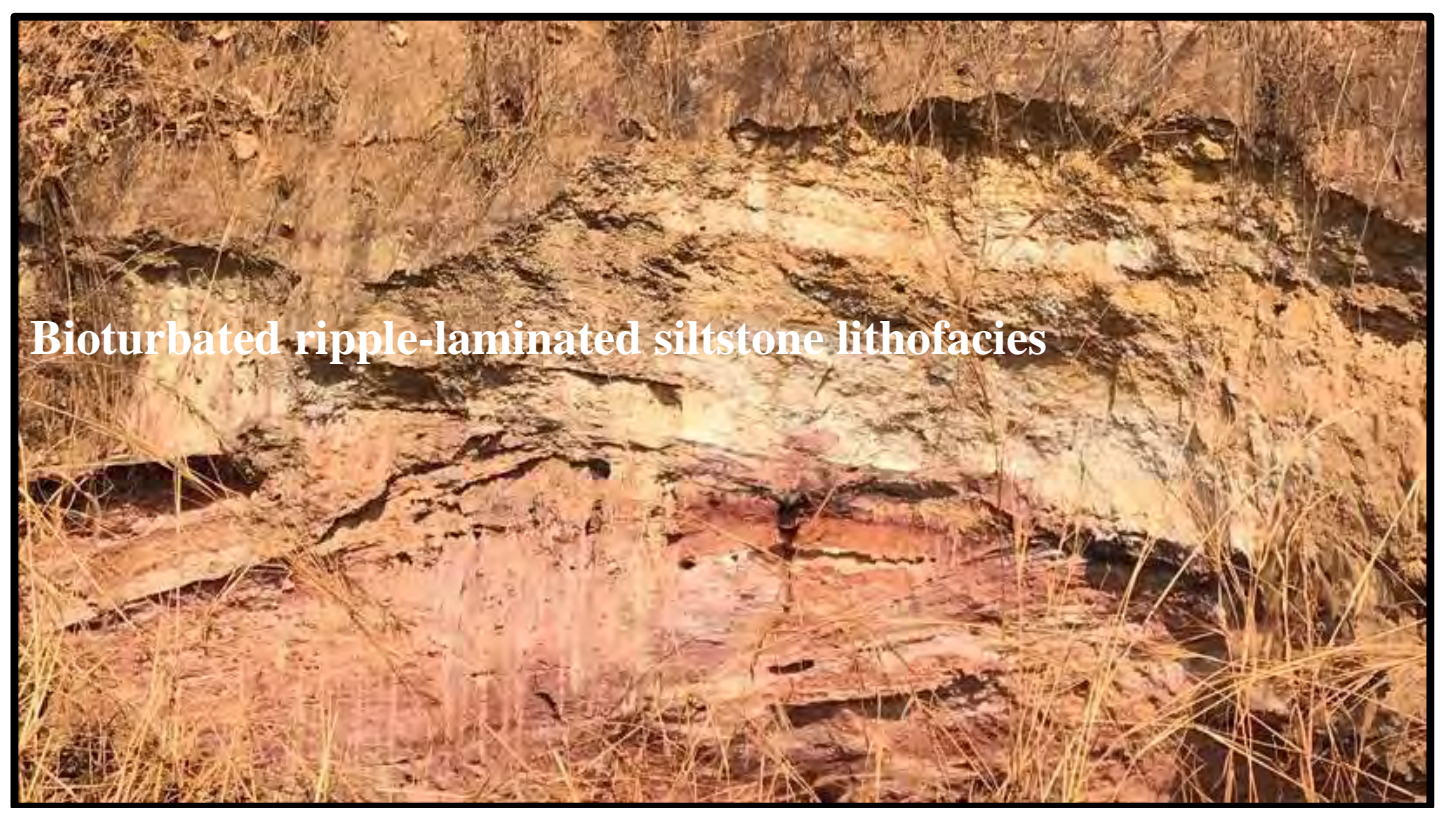

Fig. 18: Bioturbated ripple-laminated siltstone lithofacies exposed at Agbaja road section - (N $07^{\circ} 56^{\prime} 52.5^{\prime \prime}$ E $006^{\circ} 3938.2^{\prime \prime}$ Elevation - 375.3 m). 
The fine-grained, well-sorted friable bioturbated herringbone cross-bedded sandstone unit exposed at the Agbaja road section has very fine quartz and feldspar grains. The reddish-brown colouration that masks it is indicative of oxidation processes in the paleoenvironment. This unit is overlain by the wavyparallel laminated siltstone. Interpreted composite lithologic log is also presented in fig. 20 to show the exposed outcrop sections on the Lokoja - Agbaja road.

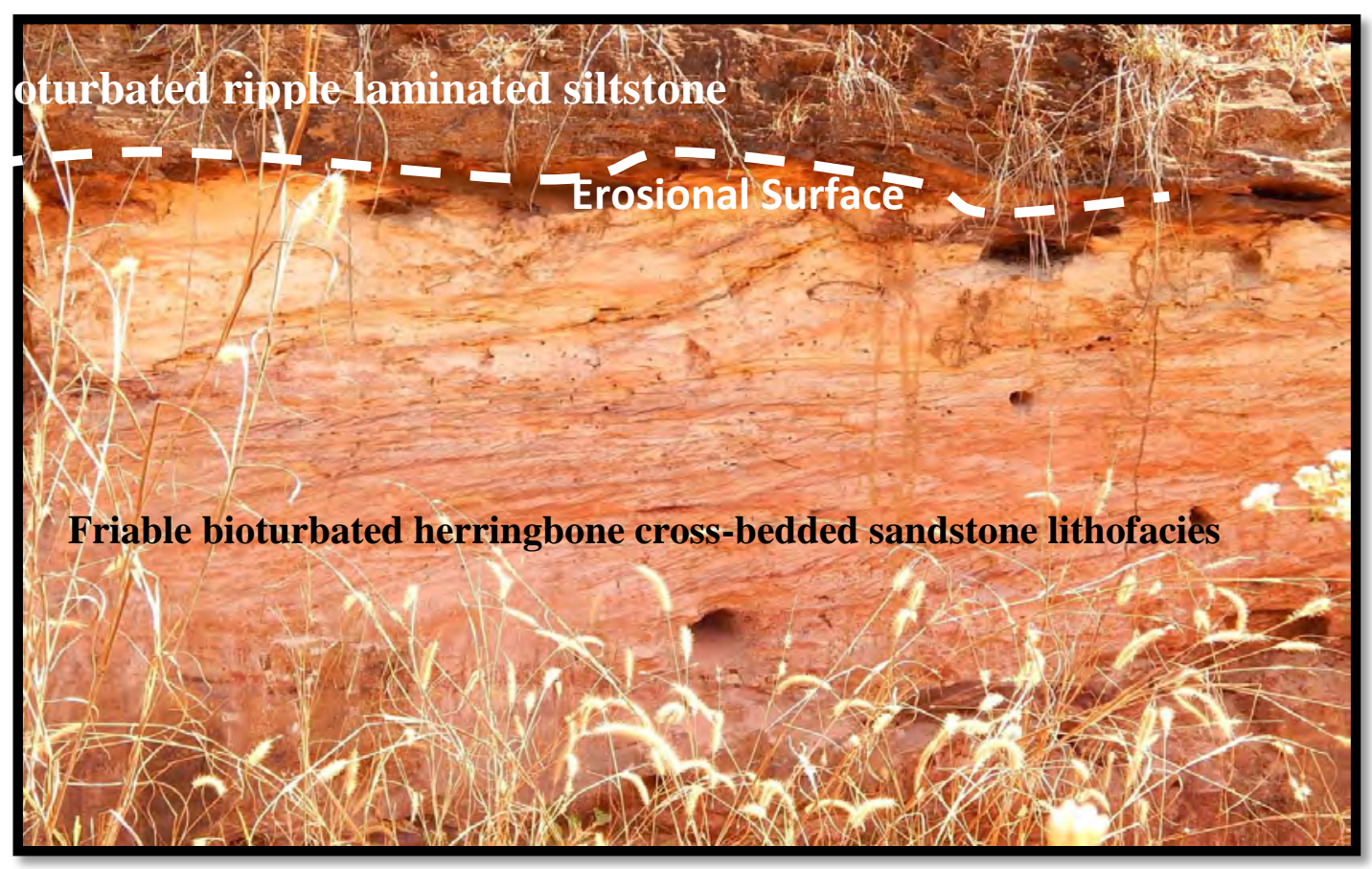

Fig. 19: Fine well-sorted friable bioturbated herringbone cross-bedded sandstone exposed at Agbaja road section - ( $07^{\circ} 56^{\prime} 52.5^{\prime \prime}$ E $006^{\circ} 3938.2^{\prime \prime}$ Elevation - $\left.375.3 \mathrm{~m}\right)$.

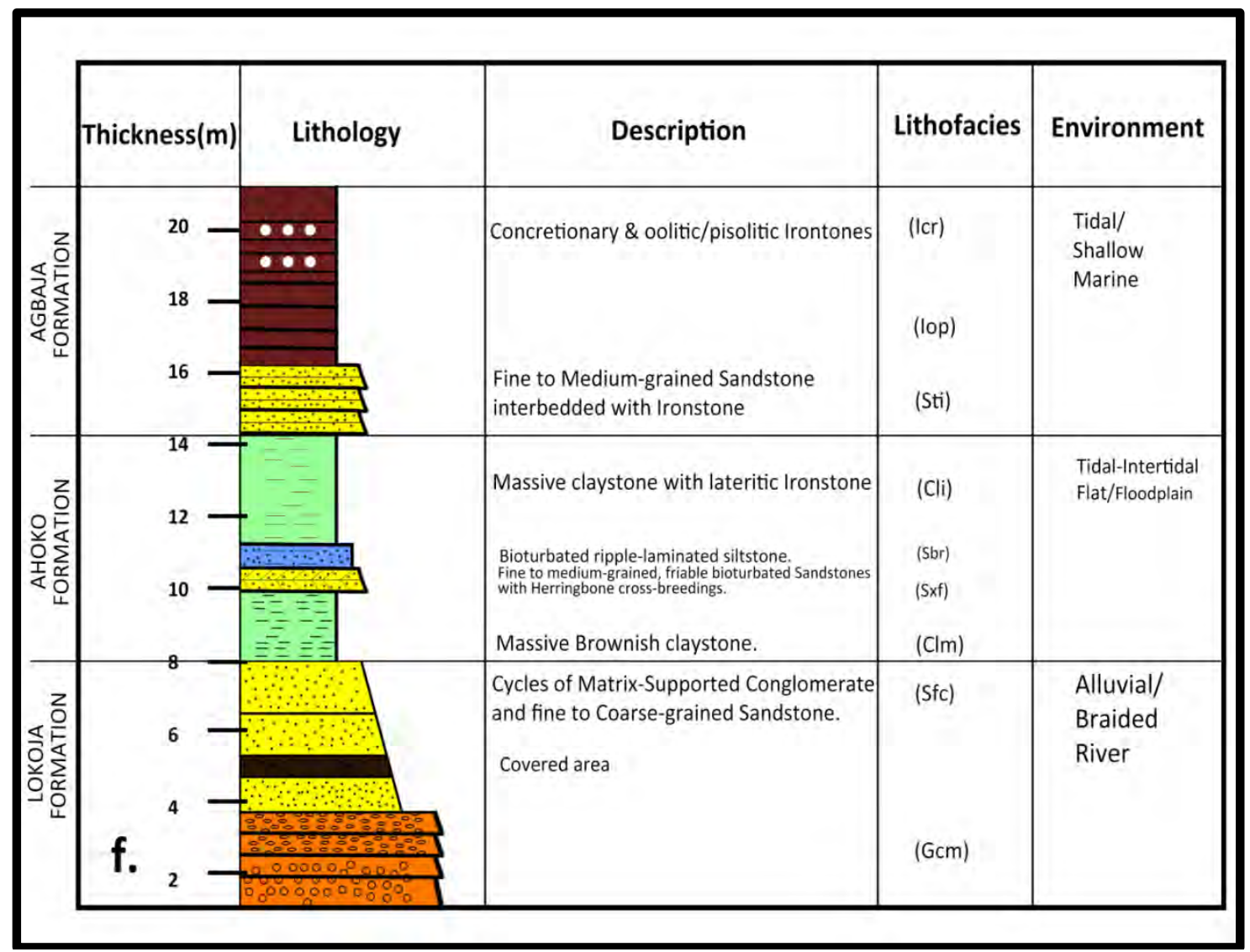

Fig. 20: Lithologic log of the exposed outcrop sections on the Lokoja - Agbaja road 


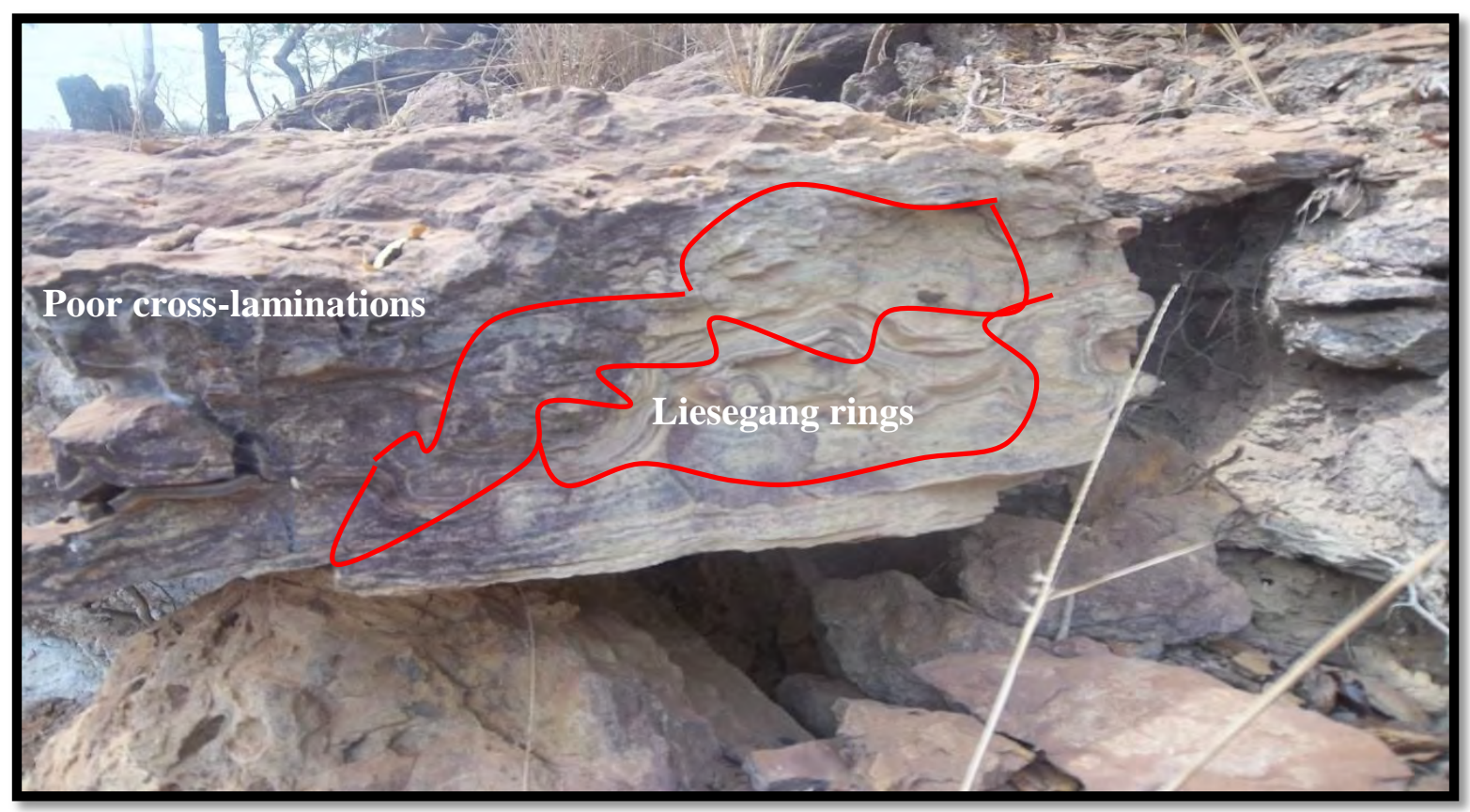

Fig. 21: Liesegang structures on poorly cross laminated claystone lithofacies exposed at the Ahoko road-cut section - $\left(\mathrm{N} 08^{\circ} 18.153^{\prime}\right.$ E $006^{\circ} 51.951$ Elevation -112.9 m. Dip of Beds: SSW 02 ${ }^{\circ}$.

The poorly cross-laminated claystone lithofacies is usually interbedded with siltstones to form a thick sequence of heteroliths. This lithofacies, which is exposed at the Ahoko road-cut section and the Aseni road-cut section, is characterized by poor laminations and liesegang structures (Fig.21).

The next lithofacies are concretionary/nodular ironstone, the medium to coarse-grained sandstone and the lateritic ironstone lithofacies. The concretionary/nodular ironstone lithofacies is exposed at the Ahoko road-cut section. This highly weathered lithofacies occur as interbeds in most places in-between ripple laminated siltstones and claystones as massive thick heteroliths (Fig. 22). Iron nodules or concretions, within sediments have been interpreted as the product of local patches from differential cementation formed at the early stages of diagenesis (Boggs, 2006). The medium to coarsegrained sandstone lithofacies have moderately sorted grains and together with siltstones, shales and claystones beds have clastic dykes cross-cutting the beds as healed fractures at the Ahoko road-cut section while the lateritic ironstone lithofacies is ironstones capping the sequence in most outcrops studied. The interpreted lithologic log is shown in fig. 23.

Ripple-laminations with slump structures, as well as the presence of nodular or concretional ironstone and liesegang ring structures in an environment indicate a shallow marine depositional process (Boggs, 2006). The presence of Ophiomorpha burrows, Chondrites and Thallasinoides trace fossils suggest a possible shallow marine - subtidal/intertidal influenced sedimentation (Stow, 2005). The combination of these chemical and biogenic sedimentary structures have been used as indices for interpreting these lithofacies: bioturbated ripple-laminated siltstone (Sbr), poorly cross-laminated claystone $(\mathrm{Cxl})$, concretionary/nodular ironstone (Icn), medium to coarse-grained sandstone (Smc), fine grained, well-sorted, friable bioturbated herringbone cross-bedded sandstone (Sxf) and lateritic ironstone lithofacies (IIt); as tidal - intertidal flat depositional environment in the Ahoko Formation. These six lithofacies have been grouped as one lithofacies association and interpreted here as deposits of a tidalintertidal flat environment. 


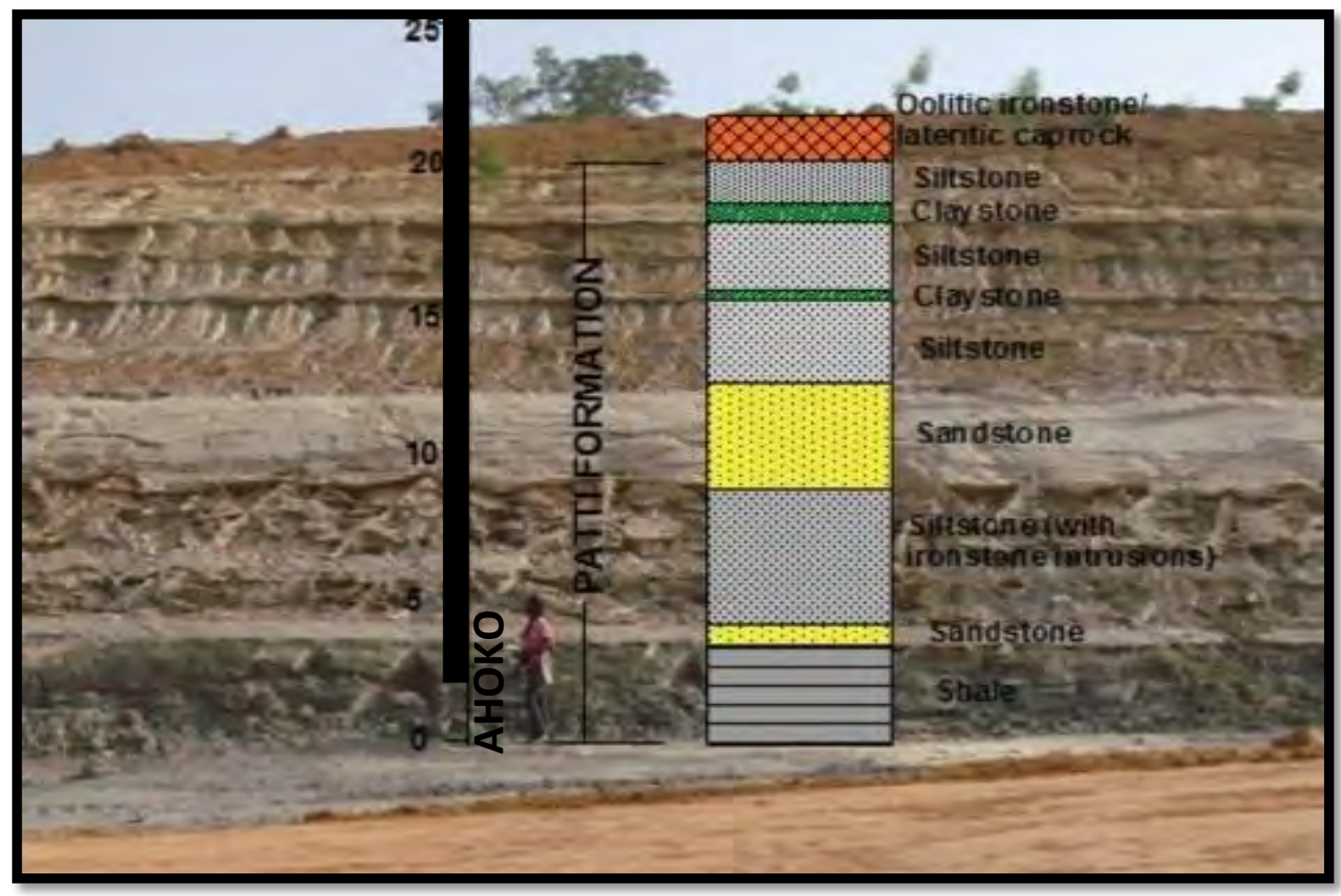

Fig. 22: Sandstone - siltstone - claystone interbeds exposed in Ahoko Village (N $08^{\circ} 18.153^{\circ} \mathrm{E} 006^{\circ} 51.951^{\prime}$ Elevation -112.9 m. Dip of Beds: SSW 02 ${ }^{\circ}$ ).

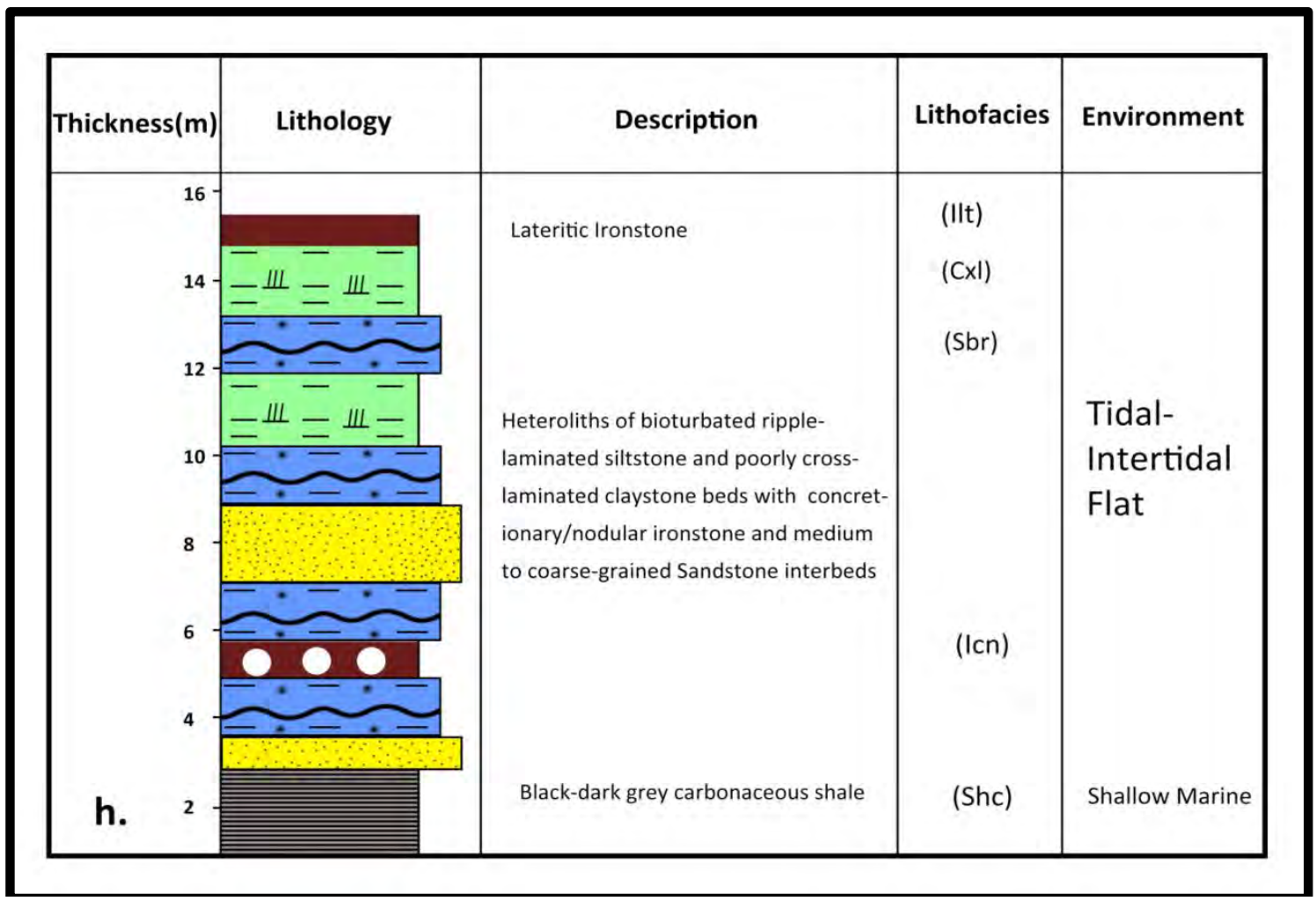

Fig. 23: Log showing sandstone - siltstone - claystone interbeds exposed in Ahoko Village

\section{FLOODPLAIN LITHOFACIES ASSOCIATION}

This lithofacies association is composed of the following lithofacies: the massive brownish claystone $(\mathrm{Clm})$, and the massive claystone - ironstone lithofacies (Cli). Both are exposed at the Agbaja road section.
The massive brownish claystone is interpreted as overbank floodplain deposits formed in an abandoned ox-bow lake while the massive claystone with lateritic ironstone inter-beds is interpreted as floodplain deposit with a tidal influence due to the presence of the ironstone interbeds (Figs. $24 \quad \& \quad 25$ ). 


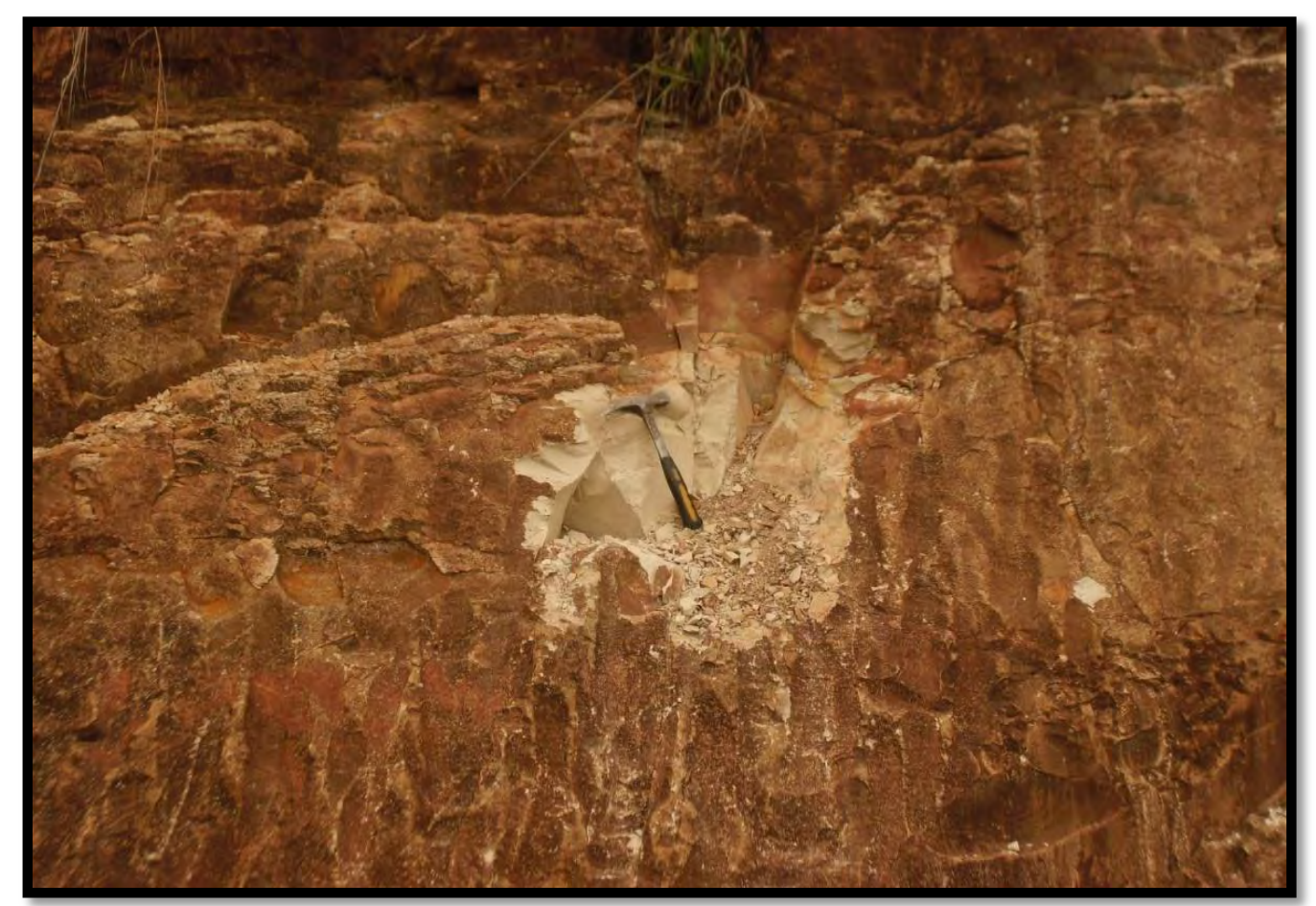

Fig. 24: Massive claystone exposed at Agbaja road section - ( $\mathrm{N} 07^{\circ} 56^{\prime} 47.7^{\prime \prime} \mathrm{E} 006^{\circ} 39^{\prime} 36.8^{\prime \prime}$ Elevation - $\left.360.1 \mathrm{~m}\right)$.

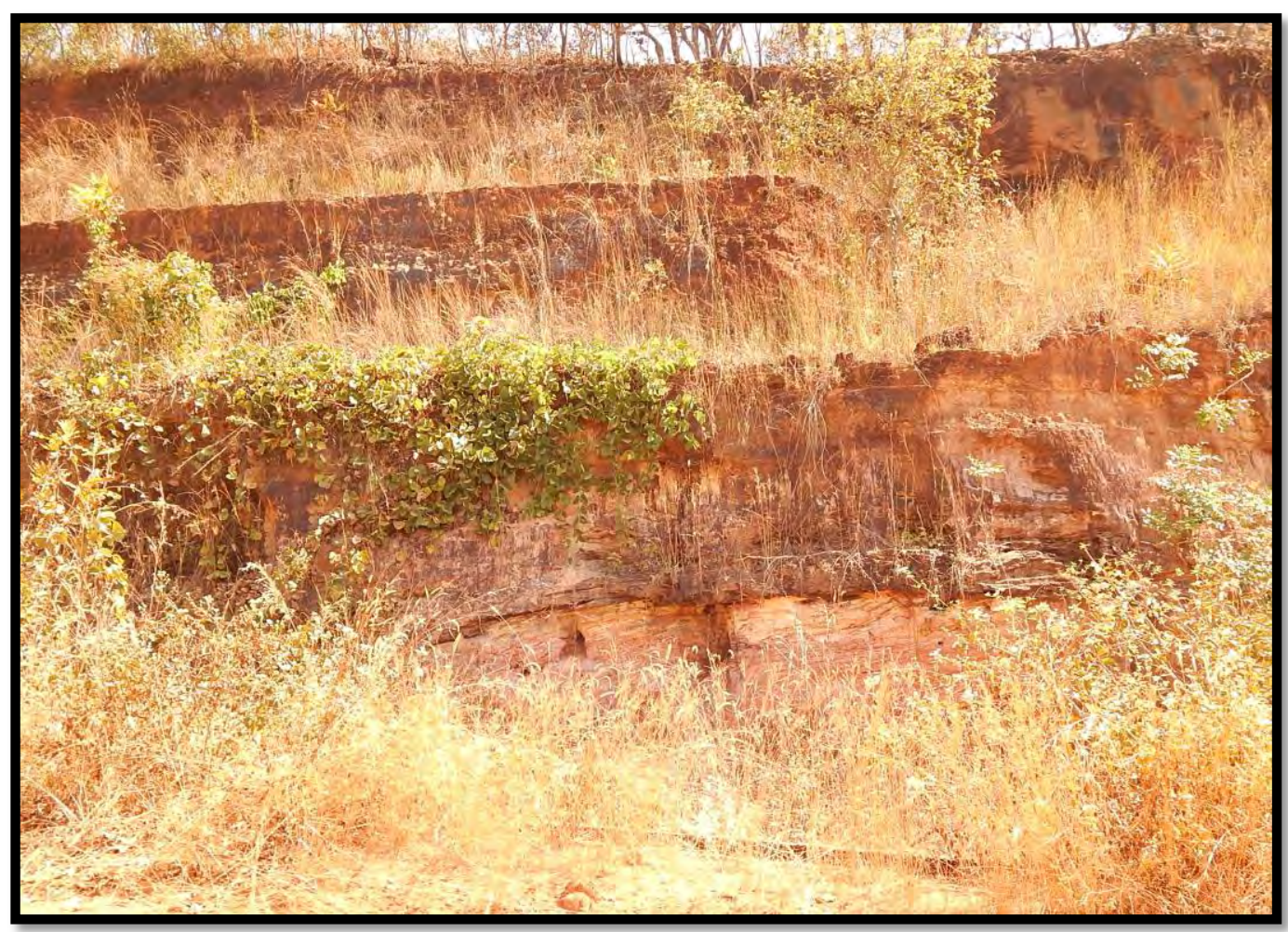

Fig. 25: Massive claystones with laterite interbedded with ironstone bands ( $07^{\circ} 5652.5^{\prime \prime} \mathrm{E} 006^{\circ} 3938.2^{\prime \prime}$ Elevation - $375.3 \mathrm{~m}$ ).

\section{LITHOFACIES OF THE AGBAJA FORMATION}

Three lithofacies were identified in the Agbaja Formation and have been grouped into two lithofacies association. These are: the fine to medium-grained sandstone with ironstone interbeds, the oolitic-pisolitic ironstone and the concretionary ironstone. The lithofacies associations are: the tidal-intertidal lithofacies association and the shallow marine lithofacies association (fig. 21).

TIDAL - INTERTIDAL LITHOFACIES ASSOCIATION

The fine to medium-grained sandstone with ironstone interbeds, constitute the tidal-intertidal lithofacies association. Ironstone bands occur as interbeds between sandstone layers (Fig. 26). 


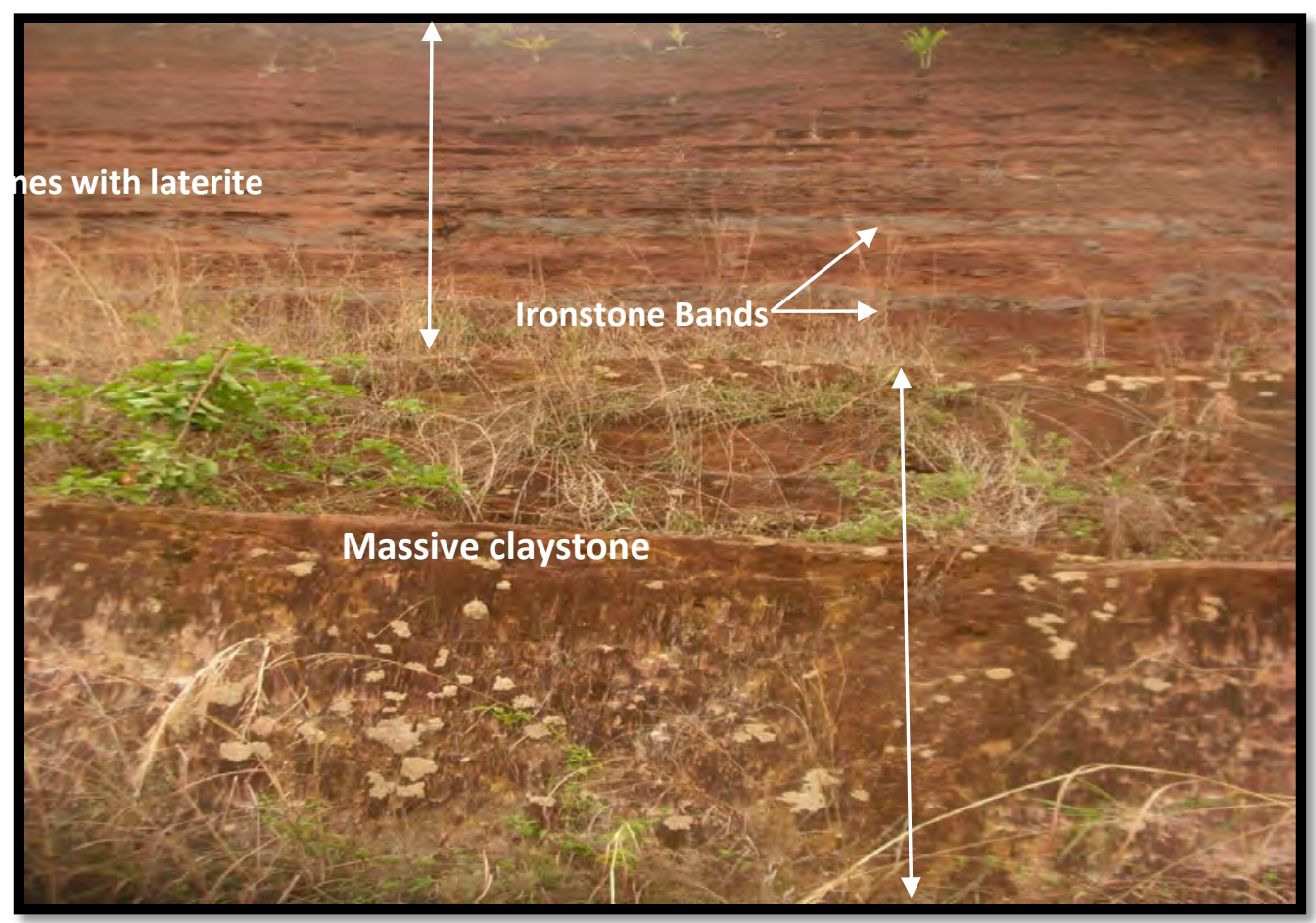

Fig. 26: Massive claystone overlain by sandstones with laterite interbedded with ironstone bands ( $07^{\circ} 56^{\prime} 54.0^{\prime \prime} \mathrm{E} 006^{\circ} 3938.1^{\prime \prime}$ Elevation $-388.6 \mathrm{~m}$. Dip of Beds: NNE $\left.04^{\circ}\right)$.

\section{SHALLOW MARINE LITHOFACIES ASSOCIATION}

The shallow marine lithofacies association begins at the lower portion of the sequence with the oolitic - pisolitic ironstone. This gradually grades into concretionary ironstone of muddy and gravelly sizes towards the upper portion. These grades of ironstones (oolitic, pisolitic, muddy and gravelly); have been referred to as the ooidal pack, pisoidal pack, detrital mud- and breccia mud forms of ironstones (Abimbola, 1997). The ironstones grade upward from oolitic to pisolitic as well as from muddy to gravel. The oolitic texture at the bottom becomes coarser and more pisolitic upwards. These deposits show precipitation from an isolated marine environment with a high influence of tidal waters influencing the nature and sizes of the iron grains. They are interpreted here as deposits of a tidally influenced shallow marine environment.

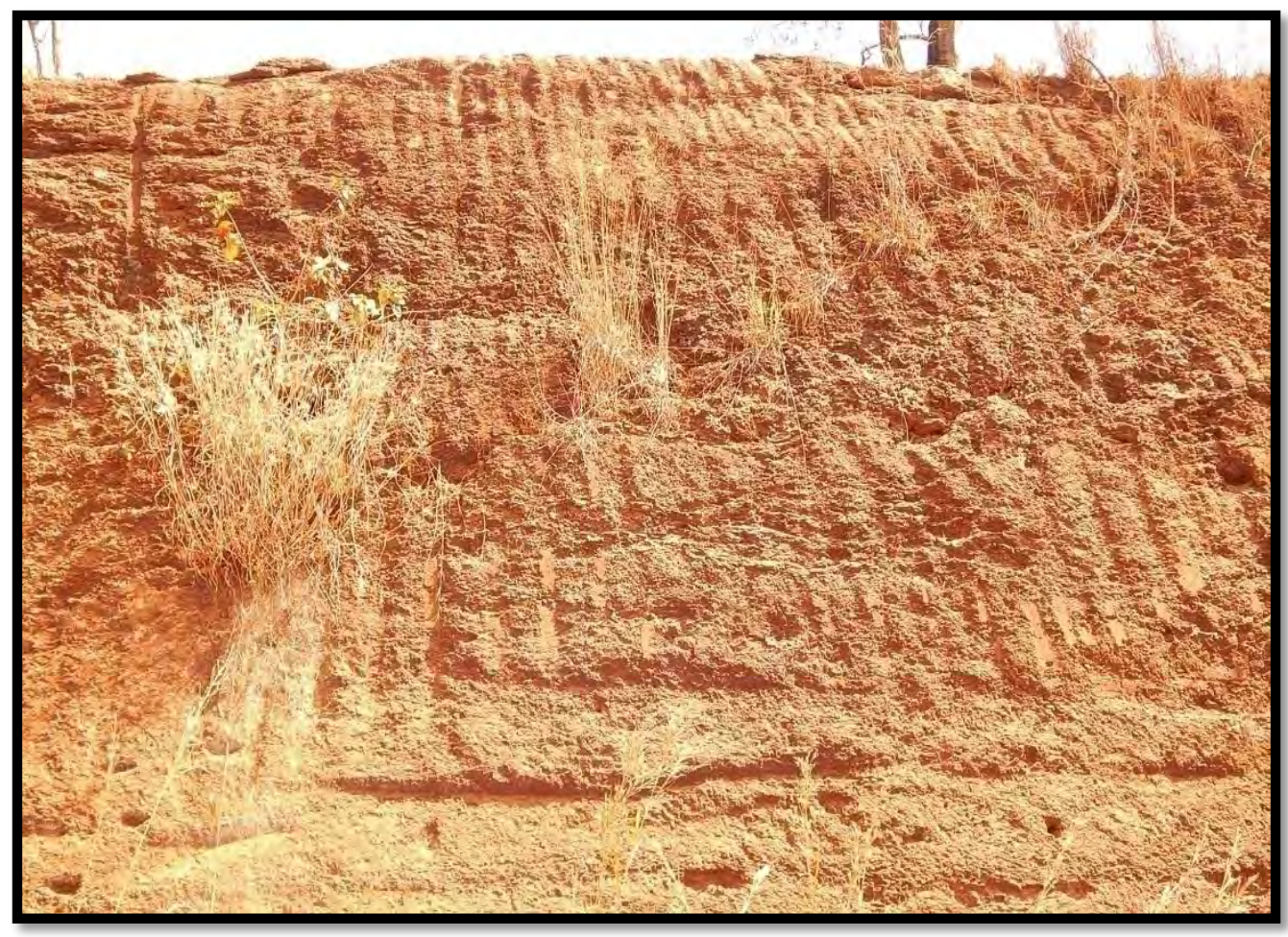

Fig. 27: Outcrop showing grades of ironstones at Agbaja road section (N $07^{\circ} 56.952^{\prime} \mathrm{E} 006^{\circ} 39.675^{\prime}$ Elevation $-390 \mathrm{~m}$. Dip of Beds: NNE $03^{\circ}$ ). 
DEPOSITIONAL ENVIRONMENT

AND

\section{DEPOSITIONAL MODEL}

The facies analysis helped in interpreting the paleoenvironment as well as developing the depositional model for the basin (Fig. 28). The lithofacies associations in the study area have been translated into distinct depositional environments for the three formations viz: Lokoja, Ahoko and Agbaja. The Lokoja Formation was developed by a continental fluvial river system which initially produced an alluvial fan environment from debris/gravity flow at its early stages. This further developed into braided river channels and later meandering river point bars during the closing stages. The clay and silt units have been interpreted as floodplains over-bank deposits. Sediments of the Ahoko Formation were deposited in shallow marine-tidal- intertidal flat and floodplain environment that formed dissected ox-bow lakes at some points while those of Agbaja Formation were essentially produced by a tidalintertidal flat system that built up into a high tidally influenced shallow marine system.

Characteristic features of the identified lithofacies in outcropping sediments found in the Southern Bida Basin have been summarized and presented in table 1. Details include: the lithofacies, lithic descriptions and formations found as well as the interpreted depositional environments. Inferences has been largely deduced from field observations of lithologic types (lithotypes), textures, sedimentary structures (physical, chemical and biogenic), bed thicknesses, contact types as well as fossil

contents.

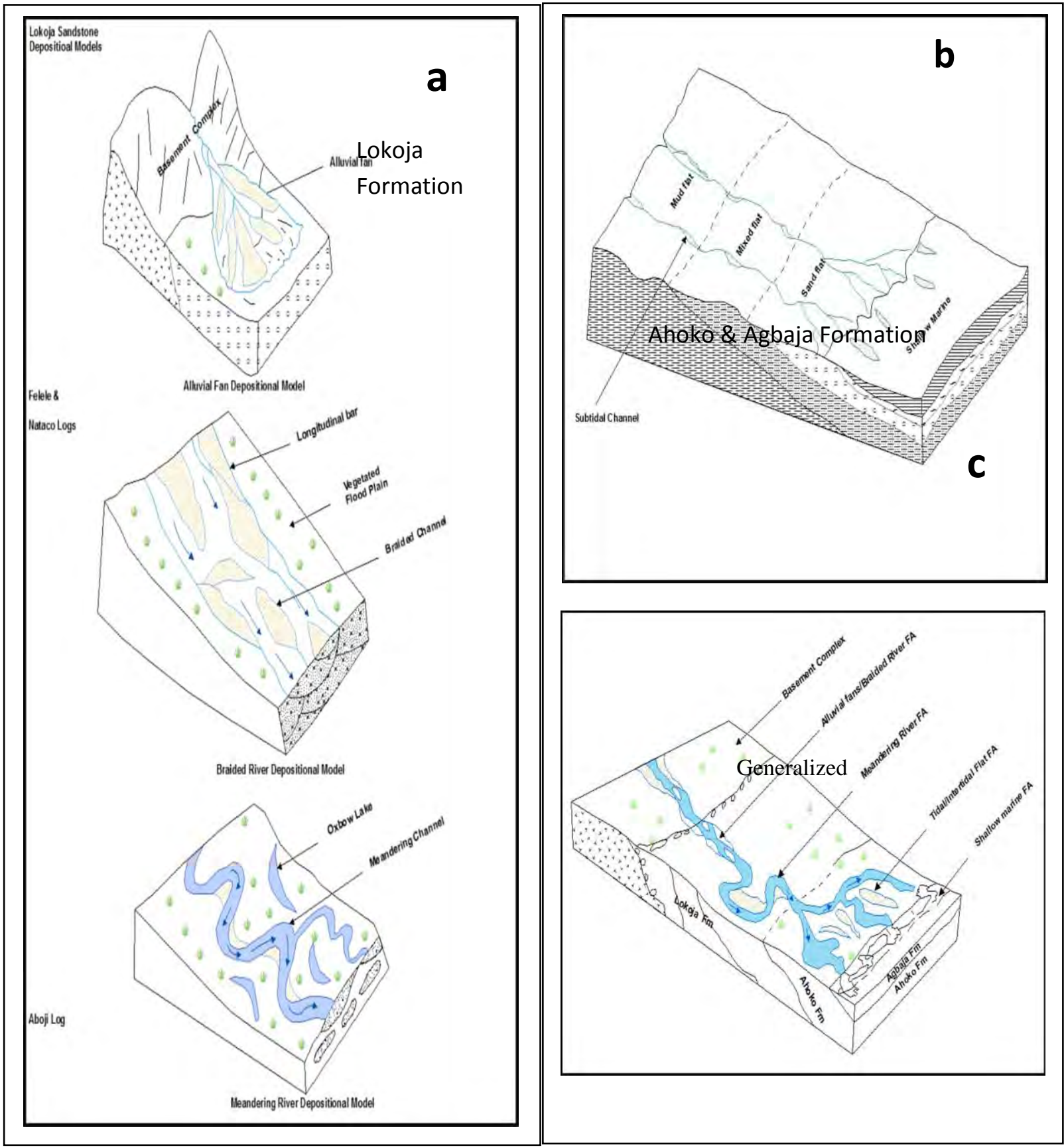

Fig. 28: Depositional models in the Southern Bida Basin: (a) Lokoja

(b) Ahoko \& Agbaja Formations (c) Generalized 
Table 1: Lithofacies and depositional environments of the Southern Bida Basin

\begin{tabular}{|c|c|c|c|c|}
\hline $\mathbf{S} / \mathbf{N}$ & FORMATION & LITHOFACIES & DESCRIPTION & $\begin{array}{l}\text { DEPOSITIONAL } \\
\text { ENVIRONMENTS }\end{array}$ \\
\hline 1. & \multirow{6}{*}{ Lokoja } & $\begin{array}{l}\text { Fanglomerate/ } \\
\text { conglomerate }-(\mathrm{Gmc})\end{array}$ & $\begin{array}{l}\text { Cobble and pebble size quartz and } \\
\text { feldspar grains that are clast/matrix } \\
\text { supported. }\end{array}$ & \multirow{6}{*}{$\begin{array}{l}\text { Debris flow/Alluvial fans } \\
\text { with Fluvial channel braid } \\
\text { bars, meandering point } \\
\text { bars and over-bank } \\
\text { floodplains. }\end{array}$} \\
\hline 2. & & $\begin{array}{l}\text { Fine to coarse-grained } \\
\text { ferruginized, weakly } \\
\text { cross-bedded, pebbly } \\
\text { sandstone - (Sxc) }\end{array}$ & $\begin{array}{l}\text { Quartz and feldspar grains with } \\
\text { imbricate pebbles embedded in } \\
\text { white/reddish-brown clay ad-mixtures or } \\
\text { drapes. Sandstones ferruginized in } \\
\text { some places with weak planar cross- } \\
\text { beddings. }\end{array}$ & \\
\hline 3. & & $\begin{array}{l}\text { Fine to coarse-grained } \\
\text { sandstones - (Sfc) }\end{array}$ & $\begin{array}{l}\text { Fine to coarse - grained quartz and } \\
\text { feldspar. }\end{array}$ & \\
\hline 4. & & $\begin{array}{l}\text { Massive silty } \\
\text { claystones - (Csm) }\end{array}$ & $\begin{array}{l}\text { Massive ferruginized claystone with tint } \\
\text { of silt. }\end{array}$ & \\
\hline 5. & & Siltstones - (SIt) & Mud-size quartz and feldspar grains. & \\
\hline 6. & & $\begin{array}{l}\text { Lateritic ironstones - } \\
\text { (llt) }\end{array}$ & $\begin{array}{l}\text { Lateritic ironstone bands with grains of } \\
\text { oolite capping outcrops. }\end{array}$ & \\
\hline 7. & \multirow{9}{*}{$\begin{array}{l}\text { Ahoko } \\
\text { Formation }\end{array}$} & $\begin{array}{l}\text { Black-dark grey } \\
\text { carbonaceous shales - } \\
\text { (Shc) }\end{array}$ & $\begin{array}{l}\text { Black to dark grey, poorly fissile, } \\
\text { carbonaceous shales. Lithofacies } \\
\text { changes laterally into mudstones } \\
\text { (claystones) at some locations. }\end{array}$ & \multirow{9}{*}{$\begin{array}{l}\text { Shallow marine to tidal- } \\
\text { intertidal flat with tidal } \\
\text { influence and overbank } \\
\text { floodplain deposits formed } \\
\text { in abandoned ox-bow } \\
\text { lake. }\end{array}$} \\
\hline 8. & & $\begin{array}{l}\text { Bioturbated ripple- } \\
\text { laminated siltstones - } \\
\text { (Sbr) }\end{array}$ & $\begin{array}{l}\text { Yellowish siltstone with ripple- } \\
\text { laminations, slump and liesegang } \\
\text { structures and burrows of Chondrites, } \\
\text { Thallasinoides and Ophiomorpha. }\end{array}$ & \\
\hline 9. & & $\begin{array}{l}\text { Poorly cross- } \\
\text { laminated claystones - } \\
(\mathrm{Cxl}) \text {, }\end{array}$ & $\begin{array}{l}\text { Claystone poorly cross-laminated and } \\
\text { interbedded with siltstones to form thick } \\
\text { heteroliths. }\end{array}$ & \\
\hline 10. & & $\begin{array}{l}\text { Concretionary/nodular } \\
\text { ironstones - (Icn) }\end{array}$ & $\begin{array}{l}\text { Highly weathered ironstones with } \\
\text { concretionary/nodular structures in } \\
\text { between heterolithic sequence. }\end{array}$ & \\
\hline 11. & & $\begin{array}{l}\text { Medium to coarse- } \\
\text { grained sandstones - } \\
(\mathrm{Smc}) \text {, }\end{array}$ & $\begin{array}{l}\text { Clastic dykes crosscutting beds as } \\
\text { healed fractures. }\end{array}$ & \\
\hline 12. & & 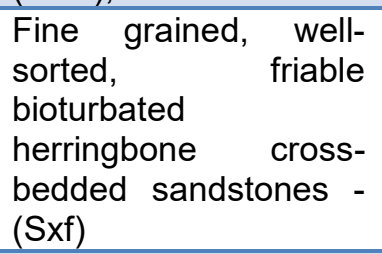 & $\begin{array}{l}\text { Reddish-brown, well-sorted, } \\
\text { grained, friable, bioturbated } \\
\text { herringbone cross-beddings. }\end{array}$ & \\
\hline 13. & & $\begin{array}{l}\text { Lateritic ironstones - } \\
\text { (llt) }\end{array}$ & $\begin{array}{l}\text { Lateritic ironstone bands with grains of } \\
\text { oolite capping outcrops. }\end{array}$ & \\
\hline 14. & & $\begin{array}{l}\text { Massive brownish } \\
\text { claystone }(\mathrm{Clm})\end{array}$ & $\begin{array}{l}\text { Massive claystone masked with brown } \\
\text { colouration. }\end{array}$ & \\
\hline 15. & & $\begin{array}{l}\text { Massive claystone } \\
\text { with lateritic ironstone } \\
\text { interbeds (Cli). }\end{array}$ & $\begin{array}{l}\text { Massive claystone occurring with } \\
\text { lateritic ironstone interbeds. }\end{array}$ & \\
\hline 16. & \multirow{3}{*}{$\begin{array}{l}\text { Agbaja } \\
\text { Formation }\end{array}$} & $\begin{array}{l}\text { Fine to medium- } \\
\text { grained sandstone - } \\
\text { ironstone interbeds } \\
\text { (Sti), }\end{array}$ & $\begin{array}{l}\text { Sandstone occurring with ironstone } \\
\text { interbeds. }\end{array}$ & \multirow{3}{*}{$\begin{array}{l}\text { Tidal-intertidal to Shallow } \\
\text { marine environment. }\end{array}$} \\
\hline 17. & & 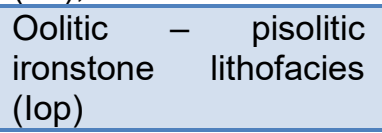 & $\begin{array}{l}\text { Ironstone of pisolitic to oolitic grain } \\
\text { sizes. }\end{array}$ & \\
\hline 18. & & $\begin{array}{l}\text { Concretionary } \\
\text { ironstone lithofacies } \\
\text { (Icr). }\end{array}$ & Ironstone formed as concretions. & \\
\hline
\end{tabular}




\section{GEOLOGIC MAP}

Outcrops of the Lokoja Formation are exposed in Felele, Nataco, Banda, Ohono up to Koton-Karfe along the Okene - Lokoja - Abuja highway while those of Ahoko Formation (former Patti Formation) are exposed in Orehi, Garba, Achabo, Idu, Gegu-Beki, Etegi, Ahoko, Gerinya and Aseni villages along the Lokoja - Abuja highway and at Gerinya along the Gegu-Beki - Gerinya road. Exposed portions at the Agbaja road section, presented a graphic view of the Lokoja Formation, part of the Ahoko Formation and the Agbaja Formation. The geologic map drawn shows the different lithologic units in the study area while the cross section shows the

stratigraphic sequence (Fig.

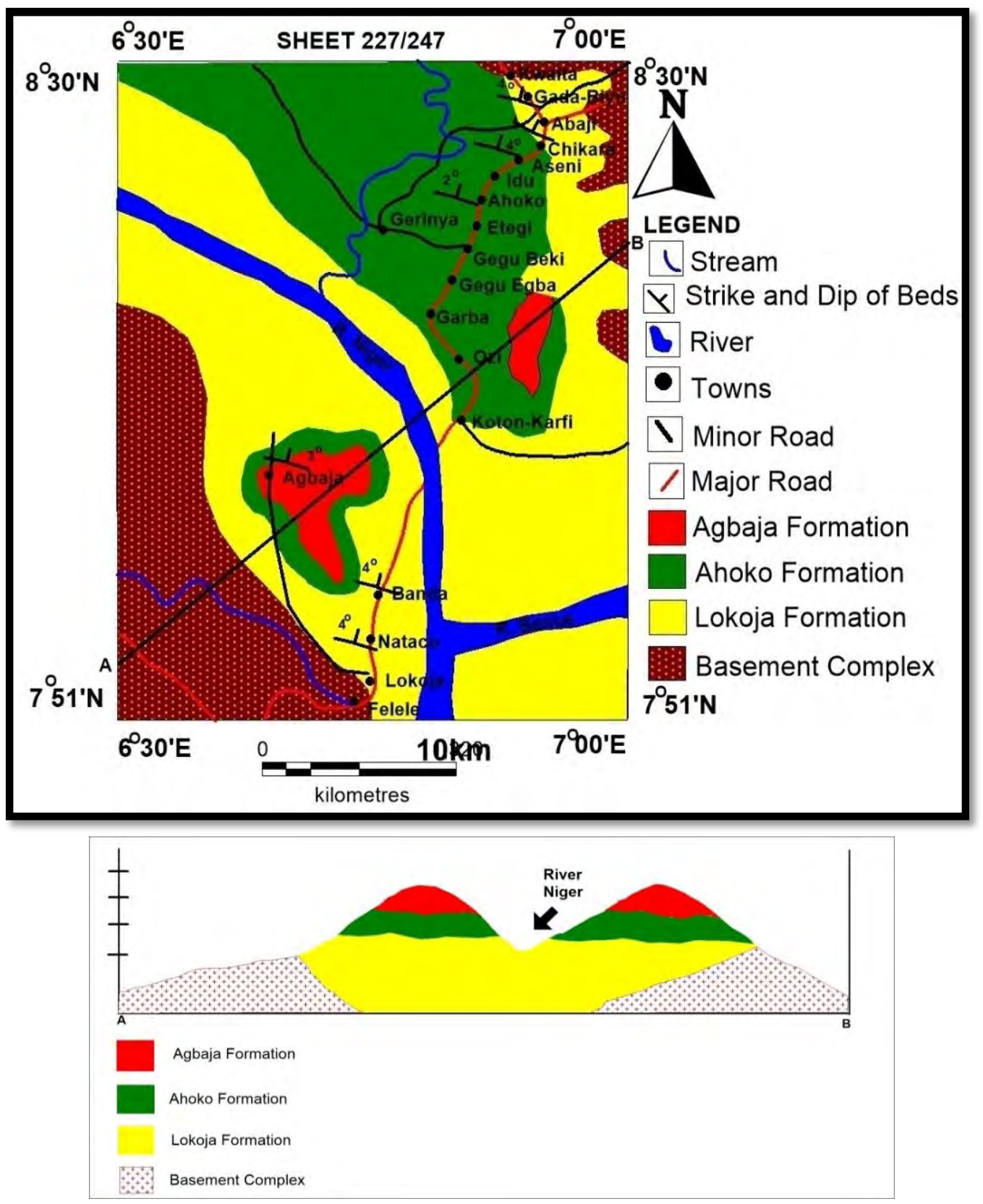

Fig. 29: Geologic map and cross-section of the Southern Bida Basin

\section{CONCLUSION}

The present study aimed at evaluating the lithologic facies or lithofacies of the sedimentary fills in the southern Bida Basin as well as interpreting their depositional environments. Systematic outcrop description, using observable field characteristics, helped in critically evaluating the different lithofacies of Lokoja, Ahoko and Agbaja Formations. The result of this lithofacies analysis was then used to correctly interpret their depositional environments. Lokoja Formation is interpreted as a fluvial dominated environment developed by a continental fluvial river system which initially produced an alluvial fan from debris/gravity flow at its early stages. This developed further into braided river channels and later meandering river point bars during the closing stages. Sediments of the Ahoko Formation were deposited in tidal/intertidal flats and shallow marine environments while sediments of the Agbaja Formation were produced by a shallow marine system that has a high tidal influence.

\section{REFERENCES}

Abimbola, F. A., 1997. Petrographic and Paragenetic studies of the Agbaja Ironstone Formation, 
Nupe Basin, Nigeria, Journal of African Earth Science 25:169-181.

Adeleye, D. R., 1973. Origin of Ironstones, an example from the Middle Niger Valley, Nigeria Journal of Sedimentary Petrology. 43: 709-727.

Adeleye, D. R., 1974. Sedimentology of the fluvial Bida sandstones (Cretaceous) Nigeria, Sedimentary Geology, 12. 1-24.

Adeleye, D. R., 1989. The Geology of the Middle Niger Basin, In Kogbe, C. A., (Ed.), Geology of Nigeria, $2^{\text {nd }}$ edition, Rock View (Nigeria) Limited Jos, Nigeria, 335-339.

Agyingi, C. M., 1991. Geology of Upper Cretaceous rocks in the Eastern Bida, Nigeria, Unpublished Ph.D. Thesis, Department of Geology, University of Ibadan, 501pp.

Akande, S. O., Ojo, O. J., Erdtmann , B. D., and Hetenyi, M., 2005. Paleoenvironments, Organic Petrology and Rock-Eval Studies on Source Rock Facies of the Lower Maastrichtian Patti Formation, Southern Bida Basin Nigeria, Journal of African Earth Sciences, 8. 394-406.

Akande, S. O., Ojo, O. J., Adekeye, O. A., and Ladipo, K. O., 2006. A Geological Field Guide to the Southern Bida Basin. Nigerian Association of Petroleum Explorationists (NAPE), $24^{\text {th }}$ Annual Conference and Exhibition, Abuja, $21 \mathrm{p}$.

Benkhelil, J., 1989. The origin and Evolution of the Cretaceous Benue Trough, Nigeria, Journal of African Earth Sciences. 8. 251-282.

Boggs, S. J., 2006. Principle of Sedimentology and Stratigraphy, Person Printing Hall Upper Saddle River, New Jersey, $4^{\text {th }}$ Edition. 662p.

Braide, S. P., 1992a Syntectonic Fluvial Sedimentation in the Central Bida Basin, Journal of Mining and Geology. 28. (1), 55-63.

Braide, S. P., 1992b. Geological Development, Origin and Energy Mineral Resources Potential of the Lokoja Formation in the Southern Bida Basin, Journal of Mining and Geology. 28. (2).33-44.

Braide, S. P., 1992c. Alluvial Fan Depositional Model in the Northern Bida Basin, Journal of Mining and Geology. 28. (1).65-73.
Nton, M. E., and Adamolekun, O. J., 2016. Sedimentological and Geochemical Characteristics of Outcrop Sediments of Southern Bida Basin, Central Nigeria: Implications for Provenance, Paleoenvironment and Tectonic History, Ife Journal of Science, 18: 2. 345-369.

Nwajide, C. S., 2013. Geology of Nigeria's Sedimentary Basins, CSS Press. 565p.

Obaje, N. G., Musa, M. K., Odoma, A. N. and Hamza, H., 2011. The Bida Basin in North-Central Nigeria: Sedimentology and Petroleum geology, Journal of Petroleum and Gas Exploration Research. 1. (1): 001-013.

Obaje, N. G., Balogu, D. O., Idris-Nda, A., Goro, I. A., Ibrahim, S. I., Musa, M. K., Dantata, S. H., Yusuf, I., Mamud-Dadi, N., Kolo, I. A., 2013. Preliminary Integrated Hydrocarbon Prospectivity Evaluation of the Bida Basin in North Central Nigeria, Petroleum Technology Development Journal. 3. (2): 41-71.

Ojo, O. J., and Akande, S. O., 2006. Sedimentology and palynological studies of the Patti Formation, southern Bida Basin, Nigeria: Implications for paleoenvironments and paleogeography, Nigeria Association of Petroleum Explorationists (NAPE) Bulletin. 19: 61-77.

Ojo, O. J., and Akande, S. O., 2008. Microfloral assemblage, age and paleoenvironment of the Upper Cretaceous Patti Formation, southern Bida Basin, Nigeria, Journal of Mining and Geology. 44: 71-78.

Ojo, O. J., and Akande, S. O., 2009. Sedimentology and depositional environments of the Maastrichtian Patti Formation, southeastern Bida Basin, Nigeria, Cretac. Res. 30, 1415-1425.

Okoro, A. U., and Ezeh, H. N., 2010. Finite Markov Chain Model in Lithofacies Analysis: An Example from the Bida Sandstone, Bida Basin, Nigeria, Global Journal of Geological Sciences, $8: 1,1-23$.

Okoro, A. U., Onuigbo, E. N., Akpunonu, E. O., and Obiadi, I. I., 2012. Lithofacies and Pebble Morphogenesis: Keys to Paleo-environmental Interpretation of the Nkporo Formation, Afikpo Sub-Basin Nigeria, Journal of Environment and Earth Science. 2. (6): 26-39. 
Omali, A. O., Imasuen, O. I. and Okiotor, M. E., 2011. Sedimentological Characteristics of Lokoja Sandstone Exposed at Mount Patti, Bida Basin, Nigeria, Advances in Applied Science Research. 2 (2): 227-245.

Osokpor, J., and Okiti, J., 2013. Sedimentological and Paleodepositional Studies of Outcropping Sediments in Parts of Southern Middle Niger Basin, International Journal of Science and Technology (IJST), 12: 839-846.

Osokpor, J., Okiti, J., Ekuerugbe, L. O., and Osokpor, O. J., 2013. Paleodepositional Environment and Sequence Stratigraphy of Outcropping Sediments in Parts of Southern Middle Niger Basin, Nigeria, Journal of Environmental and Earth Sciences. 3. (9): 152-170.

Rahaman, M. A. O., Fadiya, S. L., Adekola, S. A., Coker, S. J., Bale, R. B., Olawoki, O. A., Omada, I. J., Obaje, N. G., Akinsape, O. T., Ojo,
G. A., and Akande, W. G., 2019. A Revised Stratigraphy of the Bida Basin, Nigeria, Journal of African Earth Sciences, Elsevier. 151: 67-81.

Reijers, T. J. A., 1995. Lithofacies and their Associations in Tertiary Niger Delta, Nigeria. XPMW, Publication of SPDC, Nigeria.

Rodriguez, A., 1989. Reservoir Description through Facies Modelling: A Sedimentological Approach. Vision Technologies, 2(2) pp. 35-40.

Stow, D. A. V., 2005. Sedimentary Rocks in the Field: A Colour Guide, Manson Publishing Ltd, 73 Corringham Road London NW 11 7DL, UK. $320 p$.

Walker, R. G., 1984. Sandy fluvial Systems, In R. C., Walker (ed.), Facies Model and Environmental Analysis. $3^{\text {rd }}$ Ed., Geoscience, Canada. P. 7190. 